\title{
Dinotefuran-induced morphophysiological changes in semi-engorged females Rhipicephalus sanguineus Latreille, 1806 (Acari: Ixodidae) ticks: Ultra-structural evaluation
}

\author{
Patrícia Rosa de Oliveira ${ }^{\mathrm{a}, *}$, Luis Adriano Anholeto ${ }^{\mathrm{a}}$, Gerváso Henrique Bechara ${ }^{\mathrm{b}, \mathrm{c}}$, \\ Maria Izabel Camargo Mathias ${ }^{\text {a }}$ \\ a Department of Biology, Institute of Biosciences, São Paulo State University-UNESP, Av. 24 A, $n^{\circ}$ 1515, Postal Code 199, Zip Code: 13506-900, Rio Claro, SP, \\ Brazil \\ ${ }^{\mathrm{b}}$ Department of Animal Pathology, Faculty of Agronomic and Veterinary Sciences, São Paulo State University-UNESP, Via de Acesso Prof. Paulo Castellane, \\ s/n, Zip Code: 14884-900, Jaboticabal, SP, Brazil \\ ${ }^{\mathrm{c}}$ Graduate Program in Animal Science, School of Agricultural Science and Veterinary Medicine, The Pontificia Universidade Catolica do Parana - PUCPR, \\ Rua Imaculada Conceição, 1155, Zip Code 80215-901 Curitiba, PR, Brazil
}

\section{A R T I C L E I N F O}

\section{Article history:}

Received 21 August 2016

Received in revised form 21 October 2016

Accepted 16 November 2016

Available online 19 November 2016

\section{Keywords:}

Dinotefuran

Rhipicephalus sanguineus

Control

Acaricide

Ultrastructure

\begin{abstract}
A B S T R A C T
The present study demonstrated the effects of dinotefuran (active ingredient of the acaricide Protetor $\operatorname{Pet}^{\circledR}$ ) on the ovary and midgut cells of semi engorged $R$. sanguineus females exposed to different concentrations of this chemical. For this, 120 semi-engorged females were divided into four treatment groups with 30 individuals each: group I or control (distilled water), group II (5000 ppm), groups III (6250 ppm) and group IV (8334 ppm of dinotefuran). All the ticks were immersed in the different concentrations of dinotefuran or in distilled water for $5 \mathrm{~min}$ and then dried and kept in BOD incubator for 7 days. The results showed alterations mainly regarding the damaged cell structures, such as yolk granules, organelles and the plasma membrane of the germ cells. In addition, structures related with defense mechanisms were found, such as vacuoles, cytoskeletal filaments, and myelin figures in the germ cells. Damages in the generative cells of the midgut, alterations in the size of digestive cells, the number of endosomes, digestive vacuoles, digestive residues, lipid drops and organelles in the cytoplasm of the digestive cells and the presence of microvilli in the plasma membrane of these cells also demonstrate the progressive damages caused by the action of dinotefuran in the midgut and germ cells of $R$. sanguineus semi-engorged females. The concentrations applied partially impaired the digestive processes; and, without proper nutrition, all the ectoparasite's physiologic events are prevented from occurring, leading the individual to death. The germ cells were also damaged, and probably would not be able to advance in their development (I-V) and complete the vitellogenesis, which would affect the fertility of the female and consequently impede the formation of a new individual.
\end{abstract}

(C) 2016 Elsevier B.V. All rights reserved.

\section{Introduction}

Rhipicephalus sanguineus is probably the kind of tick that is most widely distributed in the entire world (González et al., 2004; Labruna and Pereira, 2001; Soares et al., 2006; Szabó et al., 2001).

This arthropod is the main vector of Ehrlichia canis, being also responsible for the transmission of other pathogens such as Babesia canis, B. caballi, B. equi (Sexton et al., 1976), Hepatozoon canis (Craig, 1990), Anaplasma platys (French and Harvey, 1983) and Haemo-

\footnotetext{
* Corresponding author.

E-mail address: patyrosaoliv@yahoo.com.br (P.R. de Oliveira).
}

bartonella canis (Woldehiwet and Ristic, 1993). Some studies have reported its participation in the transmission of canine visceral leishmaniasis (Coutinho et al., 2005). Others stated that $R$. sanguineus would be the vector of Coxiella burnetii - causing agent of the human Q fever (Stephen et al., 1980), Rickettsia rickettsii causing agent of spotted fever, Rickettsia conori causing agent of Boutonneuse fever (Merle et al., 1998), of simile Lyme borreliosis (Yoshinari et al., 1997) and of the Francisella tularensis bacteria, the causing agent of tularemia (Walker et al., 2000).

The main form to control these parasites still is with chemicals (through synthetic acaricides). Selection of acaricide-resistant strains of ticks and contamination of non-target organisms, as well as the environment, are factors that have encouraged investigations 
that aim at improving recent acaricides and/or developing new anti-parasite products through the identification of new pesticide molecules (Crampton et al., 1999; Nolan, 1985; Oliveira et al., 2009, 2008; Pruett, 1999). With that approach, there is also the intention of decreasing or even replacing ineffective or inappropriate synthetic products that are currently in use.

A class of substances that has the potential of controlling several plagues and that has most increased in the market since the commercialization of pyrethroids is the neonicotinoids. This promising class presents excellent chemical and biological properties, as well as low toxicity for mammals (Nauen and Bretschneider, 2002).

Among the neonicotinoids is the dinotefuran, the most recently synthetized, belonging to the third generation (Wakita, 2011; Wakita et al., 2005, 2003). The dinotefuran is unique in its structure, once it is based on the acetylcholine molecule, not on nicotine as the other neonicotinoids (Wakita, 2011). As the other neonicotinoids, it is highly toxic for the insects, mainly Hemiptera, Coleoptera, Diptera, Dictyopera and Thysanoptera (Tomizawa and Casida, 2005). Toxicological and ecotoxicological studies have demonstrated that the dinotefuran presents low toxicity for birds, aquatic animals (Kagabu, 1997; Uneme et al., 1999; Wakita et al., 2005), and the environment (EPA, 2009; Wakita, 2011; Wakita et al., 2005). Still regarding its toxicology, it was demonstrated that the dinotefuran does not have genotoxic, teratogenic or carcinogenic effects on mice, rats, rabbits of guinea pigs (Wakita et al., 2003). Its excellent chemical-physical, biological and toxicological properties make the dinotefuran a promising option to control plagues and vectors of public importance (Wakita et al., 2005; Zaim and Guillet, 2002), confirming its important role in the present context and motivating the development of studies focusing on its effects and mechanisms of action.

For Ctenocephalides felis fleas, dinotefuran has been a very efficient product (Dryden et al., 2011). However, until now, there are only few studies in literature on how to use this chemical to control the $R$. sanguineus tick.

Considering the above information, this study aimed at determining the effects of different dinotefuran concentrations in germ and midgut cells of semi-engorged $R$. sanguineus females ticks through an ultra-structural study, comparing the results obtained from the Control Group individuals, in order to understand the activity of this product in different cells and, therefore, allow the accomplishment of essential information that will help the development of new control methods of $R$. sanguineus ticks and/or improve usual and more specific control methods, which do not induce tick-resistance and are less toxic and less damaging to the environment and non-target organisms.

\section{Material and methods}

\subsection{Chemical substance}

\subsubsection{Synthetic: dinotefuran (CAS 165252-70-0)}

Dinotefuran is a compound of the neonicotinoid chemical class, molecular formula $\mathrm{C}_{7} \mathrm{H}_{14} \mathrm{~N}_{4} \mathrm{O}_{3}$. The chemical was obtained from the commercial acaricide Protetor Pet ${ }^{\circledR}$, produced by "Ouro Fino Saúde Animal”, Cravinhos, SP, Brazil, in tubes of $0.48 \mathrm{~mL}$, concentration $25 \%$, for animals up to $5.0 \mathrm{~kg}$.

\subsection{Rhipicephalus sanguineus ticks (Latreille, 1806)}

Semi-engorged $R$. sanguineus females, weighing $27 \mathrm{mg}$ on average (about five days of feeding), were used throughout the experiment. They were supplied by the tick colony maintained under controlled conditions $\left(28{ }^{\circ} \mathrm{C}, 85 \%\right.$ humidity, and 12 -h photoperiod) in a BOD (Biological Oxygen Demand) incubator, in a room of the Animal Facility of the Department of Biology - UNESP, Rio Claro Campus/São Paulo, Brazil. Semi-engorged females were obtained after unfed $R$. sanguineus couples (25 couple/infestation) were allowed to feed on naive Botucatu genetic group rabbits following Bechara et al. (1995). The semi-engorged stage of the females was chosen due to the high parasitary efficiency in this phase.

\subsection{Hosts}

Botucatu genetic group rabbits, weighing between 3 and $3.5 \mathrm{~kg}$, were used as hosts. Rabbits were obtained from the Animal Facility of UNESP - Botucatu Campus/São Paulo - Brazil and housed in the Animal Facility of UNESP - Rio Claro Campus/São Paulo - Brazil. Animals did not have prior contact with ticks or acaricides and were kept under controlled conditions. During the entire experiment, animals were maintained in cages and received water and rabbit food ad libitum.

The Ethics Committee for Animal Experimentation of UNESP/SP/Brazil, protocol n6334/2014, approved this study.

\subsection{Dinotefuran dosage}

The initial concentration of dinotefuran was defined based on the recommendations of manufacturer - product label of Protetor Pet ${ }^{\circledR}$. Several doses were evaluated in preliminary tests (pilots) by diluting dinotefuran (Protetor Pet ${ }^{\circledR}$ ) in distilled water (0 to 50\%). After this bioassay, the efficacy of dinotefuran and the level of susceptibility of the semi-engorged females were evaluated, and the lethal concentration $\mathrm{LC}_{50}$ determined was $10,182.253 \mathrm{ppm}$. In this study, the concentrations corresponded to $5000 \mathrm{ppm}, 6250 \mathrm{ppm}$ and $8334 \mathrm{ppm}$ of dinotefuran. All the concentrations of dinotefuran were kept in labeled volumetric flasks until the tests. Each treatment was conducted in duplicate.

\subsection{Experimental model}

$R$. sanguineus semi-engorged females were divided into three treated groups: group II (5000 ppm of dinotefuran), group III (6250 ppm of dinotefuran) and group IV (8334 ppm of dinotefuran). The control group was exposed only to the placebo (distilled water).

The 120 semi-engorged females of $R$. sanguineus, after being washed in a sieve with tap water, were dried on soft absorbent paper. After that, 90 females were divided into three groups of 30 females ( 30 females for each concentration -2 groups with 15 individuals - duplicates) and immersed for $5 \mathrm{~min}$ in Petri dishes containing the above different concentrations of dinotefuran. The control group was also composed of 30 females that had been immersed in distilled water for the same period. Ticks were then dried in absorbent paper and placed in the BOD incubator $\left(28 \pm 1^{\circ} \mathrm{C}\right.$, $80 \%$ relative humidity and $12 \mathrm{~h}$ photoperiod) for 7 days. The observation period was established because frequently the effect of acaricides is not immediate, but acts slowly on the physiology of the individual analyzed (Roma et al., 2010).

After 7 days of monitoring, all the semi-engorged females were forwarded to ultrastrucure techniques.

\subsection{Methods}

\subsubsection{Transmission electron microscopy}

All semi-engorged females were fixed in $2.5 \%$ glutaraldehyde for two hours, rinsed twice for 15 min each with $0.1 \mathrm{M}$ sodium cacodylate buffer, and post-fixed with $1 \%$ osmim tetroxide for two hours. The material was then rinsed twice with $0.1 \mathrm{M}$ sodium cacodylate for 15 min each. 
The material was then immersed in 10\% ethanol during 15 min, contrasted with $2 \%$ uranyl acetate and $10 \%$ ethanol for two hours, and dehydrated in a crescent series of $50 \%, 70 \%, 90 \%, 95 \%$ and $100 \%$ acetone, twice for the latter concentration, for 10 min each and $15 \mathrm{~min}$ for pure acetone. The material was then immersed in a 1:1 mixture of acetone and resin for $12 \mathrm{~h}$, and transferred to pure Epon Araldite resin with catalyzer.

Finally, the material embedded in pure Epon Araldite resin and catalyzer was placed in the oven at $60^{\circ} \mathrm{C}$ for 24 to $48 \mathrm{~h}$, and then sectioned in ultramicrotome. Sections were placed on copper grids for contrasting with uranyl acetate and lead citrate during 45 and 10 min respectively.

The grids containing the sections were examined and photographed with a JEOL JEM 1011 Transmission Electron Microscopy of the ESALQ/USP.

\section{Results}

\subsection{Transmission electron microscopy}

\subsubsection{Ovary}

3.1.1.1. Control group. The results obtained in the analysis of the semi-engorged female ovaries from the control group are similar to those obtained by Oliveira et al. (2005). Below, a summary of the main characteristics of the Rhipicephalus sanguineus female ovary.

The ovary $R$. sanguineus consists of a wall of epithelial cells and a large number of oocytes in five developmental stages, attached to the wall by a pedicel (Oliveira et al., 2005).

The oocytes I show round-shaped and central germ vesicle, little heterochromatin and the nucleolus is very evident. The cytoplasm is homogeneous, rich in free ribosomes, polyribosomes, and mitochondria in various shapes (from round and elliptical to haltershaped), located mainly in the peripheral region of the oocyte (Fig. 1B). The plasma membrane shows specializations in the form of microvilli towards the basal lamina (Fig. 1A,B). Some vesicles containing electron dense material are observed in the region between the basal lamina and the membrane (Fig. 1A,B).

The oocytes II show a round-shaped germ vesicle with dispersed chromatin. In the cytoplasm, both free ribosomes (forming polyribosomes) - and bound ribosomes (adhered to the little developed lamellar rough endoplasmic reticulum) are found (Fig. 1C,D). In addition, few and small electron lucid lipid droplets and mitochondria of various sizes, shapes and electron density occupy mainly the peripheral region of these cells (Fig. 1C,D).

The plasma membrane surrounds the oocyte II, with longer and more numerous microvilli in comparison with those found in oocytes I. The membrane is supported by thick basal lamina, and between these regions, the vesicles are still observed (Fig. 1D).

The oocytes III present numerous and small secretory granules of lipid (electron lucid) and protein (electron dense) composition (Fig. 1E,F). The largest protein granules are located in the periphery; and the smallest, in the central region of the oocyte (Fig. 1E,F). The mitochondria are still the main organelles distributed throughout the cytoplasm (Fig. 1E), as well as numerous ribosomes and lamellar rough endoplasmic reticulum (Fig. 1E,F). The plasma membrane shows several microvilli and the basal lamina is thick (Fig. 1F, G). Vesicles are observed between these regions (Fig. 1F,G).

In the oocytes IV, numerous protein granules with different sizes and electron density are found (Fig. 1H), in addition to small lipid droplets (electron lucid) and mitochondria distributed throughout the cytoplasm (Fig. 1H,I). In the periphery of the oocyte, the beginning of chorion deposition is observed, via exocytosis vesicles polymerizing in the space between the basal lamina and the plasma membrane (Fig. $1 \mathrm{H}, \mathrm{I}$ ).

The cytoplasm of the oocytes $\mathrm{V}$ is full of large and electron dense yolk protein granules, as well as small and electron lucid lipid droplets (Fig. 1J,K). The chorion is completely deposited around the oocyte and is constituted by two layers: the exochorion, the outer layer, less thick and presenting medium electron density; and the endochorion, the inner layer, thicker, little electron dense and in direct contact with the oocyte (Fig. 1J,K).

3.1.1.2. Group II. The oocytes from the individuals exposed to $5000 \mathrm{ppm}$ of dinotefuran show few alterations when compared with the control group. Most characteristics of these oocytes is not affected by this concentration.

The oocytes I show few vacuoles, including autophagic ones, located mainly next to the peripheral region (Fig. 2A,B).

The oocytes II present several vacuoles, including autophagic ones, occupying the regions next to the germ vesicle and the plasma membrane. In the latter, the number of microvilli is reduced in comparison with the oocyte II from the control group (Fig. 2C,D). Few vesicles and some myelin figures are observed between the plasma membrane and the basal lamina (Fig. 2D).

The oocytes III show several disorganized regions, affected by the chemical. The cytoplasm displays vacuoles of different sizes, many irregular protein granules with degenerated areas (small vacuoles in the interior of the granule), in addition to several autophagic vacuoles and myelin figures in the central region next to the germ vesicle and in the peripheral region as well (Fig. 2E-H). The organelles, the mitochondria and the lamellar rough endoplasmic reticulum remain intact (Fig. $2 \mathrm{E}-\mathrm{H}$ ).

The oocytes IV and $\mathrm{V}$ were not modified by the application of this concentration, as they showed similar characteristics to the oocytes IV and V from the control group (Fig. 2I,J).

The germ vesicle remains intact in all the oocytes (I, II, III, IV and V).

3.1.1.3. Group III. The individuals from group III subjected to $6250 \mathrm{ppm}$ of dinotefuran show a larger number of modified oocytes and affected areas when compared with the previous group.

The oocytes I display cytoplasmic vacuoles in the central region and in the region adjacent to the plasma membrane, probably releasing their content to the space between the plasma membrane and the basal lamina (Fig. $3 \mathrm{~A}-\mathrm{C}$ ). These vacuoles are more frequent than the oocytes I from the previous groups (Fig. 3A-C).

The oocytes II show several vacuolated areas next to the germ vesicle, to the peripheral region and adjacently to the plasma membrane (Fig. 3D-F). Several autophagic vacuoles and myelin figures are found in the cytoplasm; however, few lipid droplets are observed (Fig. 3D-F). The organelles, mitochondria and lamellar rough endoplasmic reticulum are still present.

The oocytes III show evidence of damages, with several cytoplasmic vacuoles, irregular protein granules and degraded areas in their interior, as well as autophagic vacuoles (Fig. 3G-J). Few lipid droplets, mitochondria and little developed lamellar rough endoplasmic reticulum are found throughout the cell (Fig. 3G, I, J).

The oocytes IV display few alterations, only the protein granules show a different electron density in comparison with the protein granules from the oocytes IV in the previous groups (Fig. 3K,L).

The oocytes V contain large yolk protein granules. Some small round-shaped vacuoles are found, mainly in the periphery. The chorion is subdivided and is still thick as in the previous stages (Fig. 3M)

The germ vesicle remains intact in all the development stages of the oocytes (I, II, III, IV and V).

3.1.1.4. Group IV. The ovaries of the individuals from group IV present numerous oocytes with large degraded areas, indicating the damages caused by the dinotefuran.

The oocytes I show higher cytoplasmic vacuolation (located in the peripheral region) in comparison with those from the previous groups (Fig. 4A,B). The organelles, mitochondria and the lamellar 

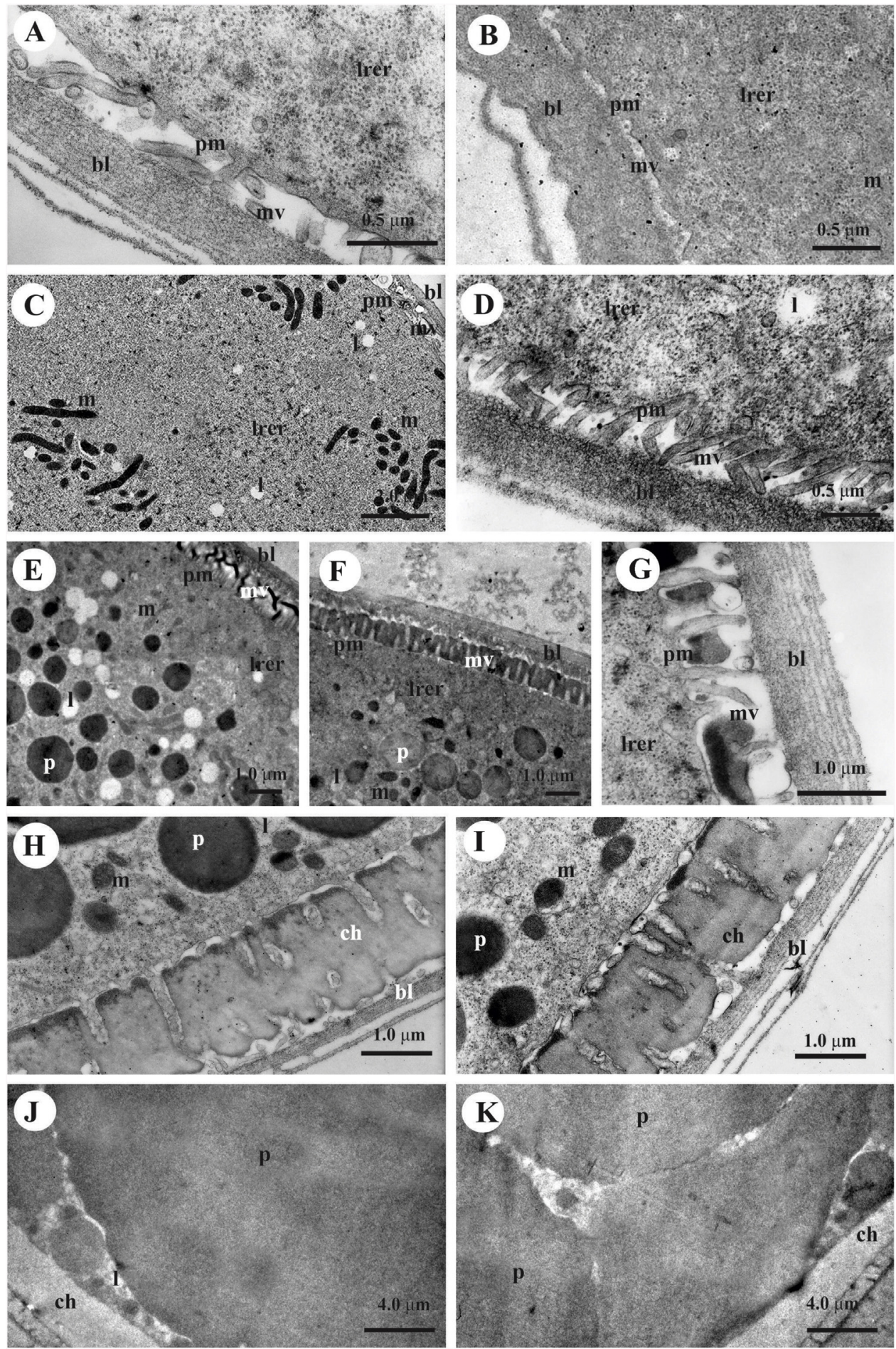

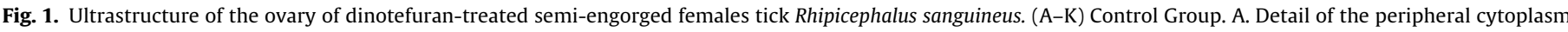

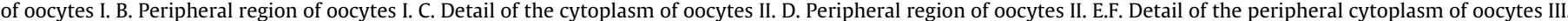

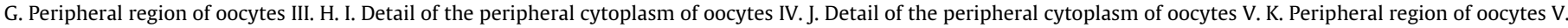

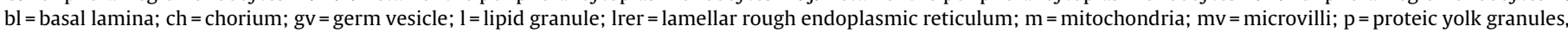
$\mathrm{pm}=$ plasma membrane .

rough endoplasmic reticulum are present. In the peripheral region, the membrane containing microvilli and the thick basal lamina are still being observed (Fig. 4A,B).

The oocytes II present extensive vacuolation in the region next to the vesicle and in the peripheral region as well (Fig. 4C-F). Autophagic vacuoles and myelin figures are observed in the peripheral cytoplasm (Fig. 4C-F). Rare lipid droplets, few mitochondria and a little developed lamellar rough endoplasmic reticulum are present, in addition to a well-developed vesicular rough endoplasmic reticulum (Fig. 4C-F).

The oocytes III show extensive vacuolation mainly in the peripheral region of the cell (Fig. 4G-K). Irregular protein granules with several degraded areas, autophagic vacuoles and cytoskeleton elements are observed (Fig. 4G-K). Lipid droplets are seldom 

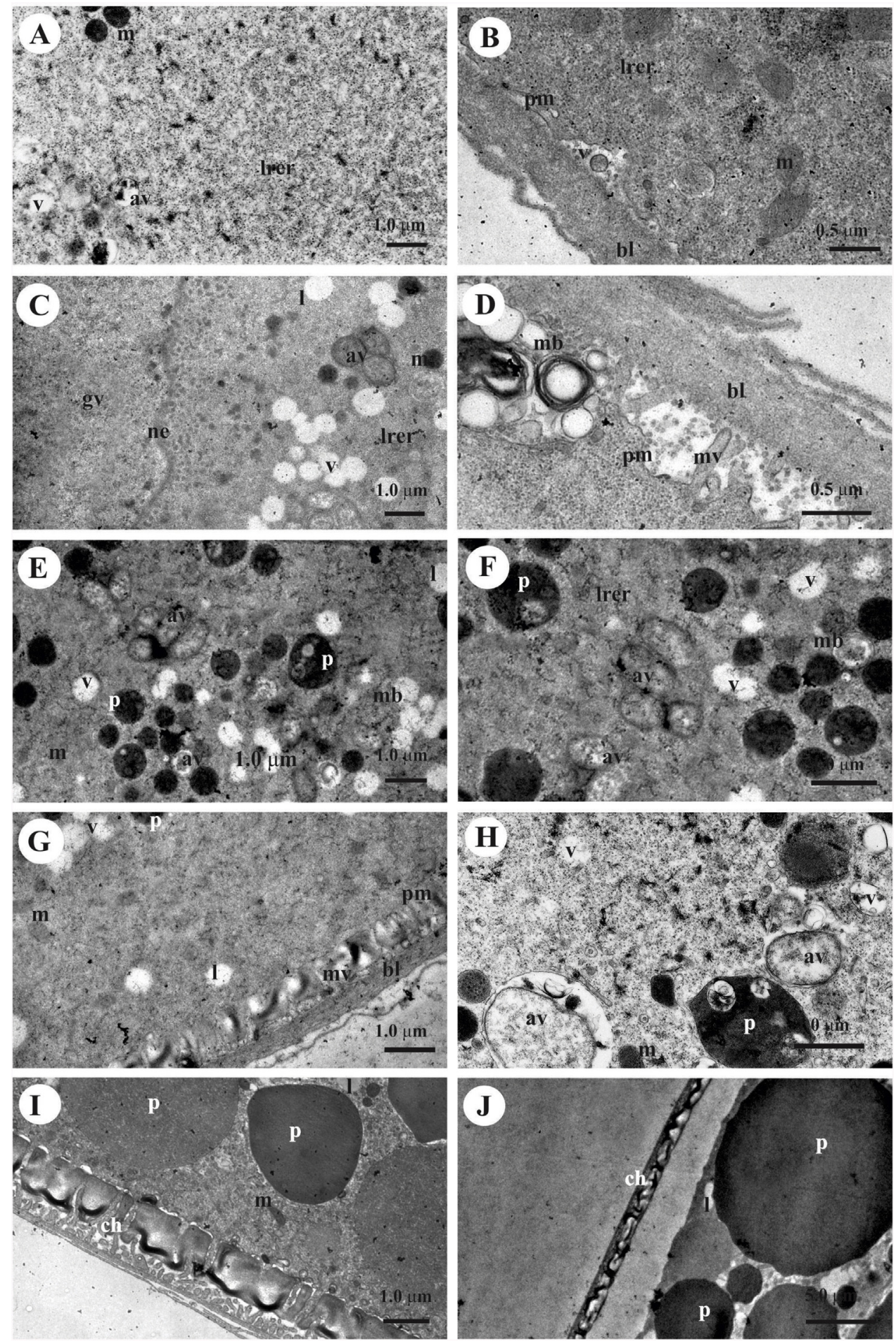

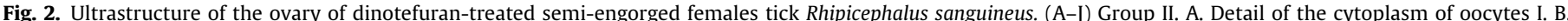

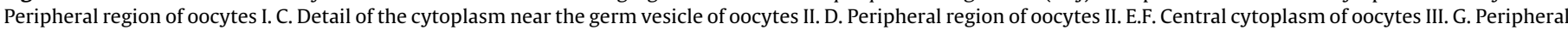

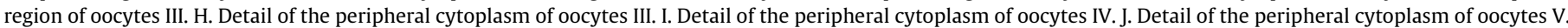

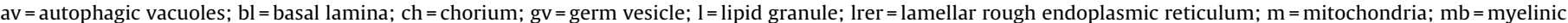
bodies; $\mathrm{mv}=$ microvilli; $\mathrm{ne}=$ nuclear envelope; $\mathrm{p}=$ proteic yolk granules; $\mathrm{pm}=$ plasma membrane; $\mathrm{v}=$ vacuoles .

observed. The number of organelles is also reduced, few mitochondria are present and the lamellar rough endoplasmic reticulum is little developed (Fig. 4G-K). Only the vesicular endoplasmic reticulum is developed (intense vacuolation of the rough endoplasmic reticulum). The number of microvilli in the periphery is smaller in comparison with the oocytes III from the previous groups (Fig. 4J). In this region, both the microvilli and the basal lamina are modified; the former are disorganized, and, in the latter, the outer layer is separated from the inner one, showing irregularities (Fig. 4J).

The oocytes IV show round-shaped vacuoles mainly among the large yolk protein granules (Fig. 4L,M). Lipid droplets and mitochondria are seldom observed. The lamellar rough endoplasmic reticulum is little developed and under vesicular form appears only 

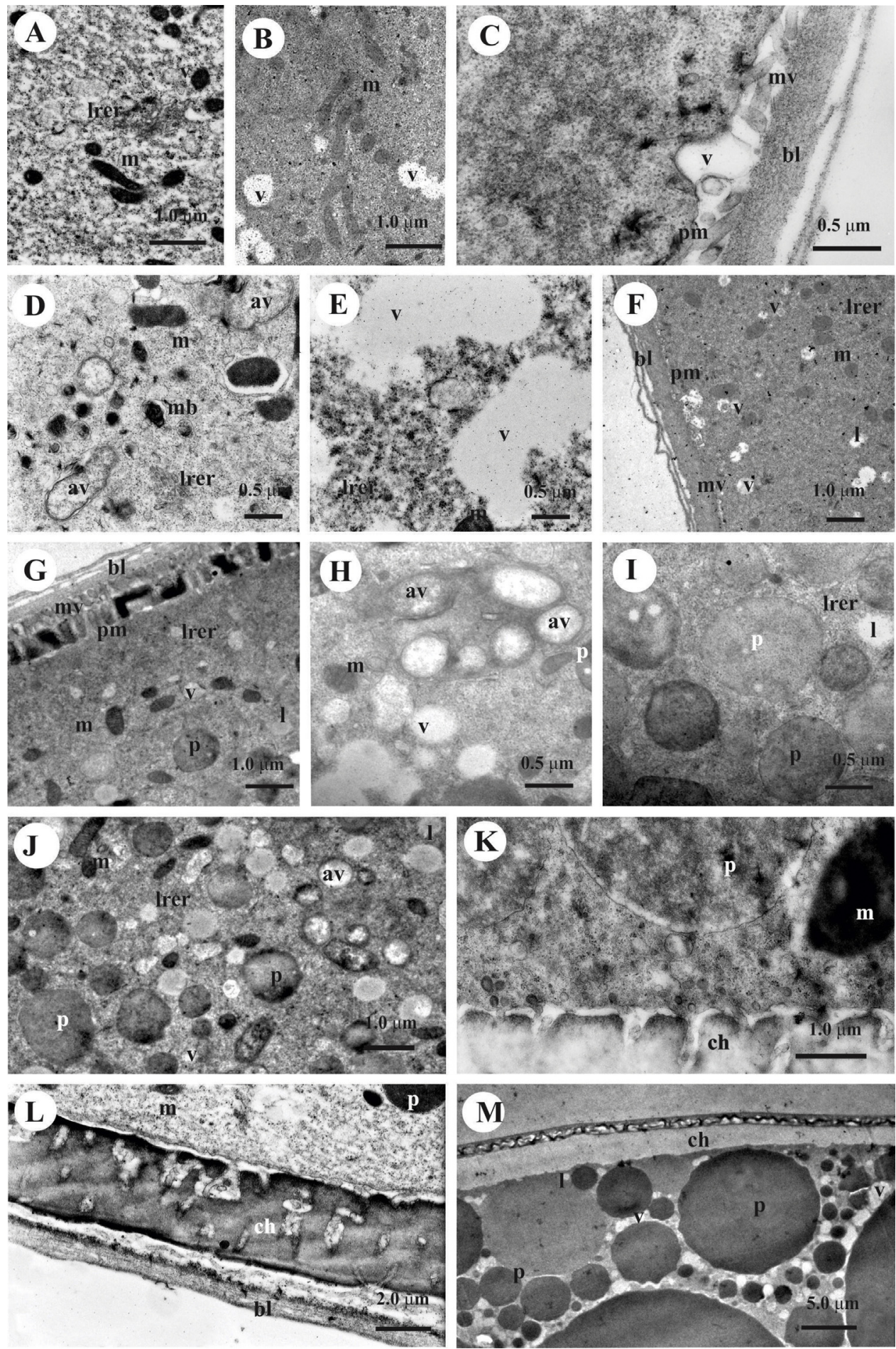

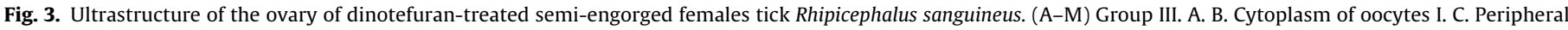

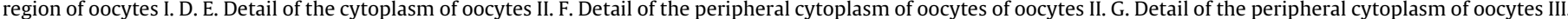

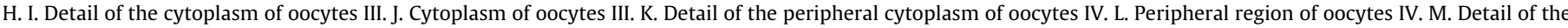

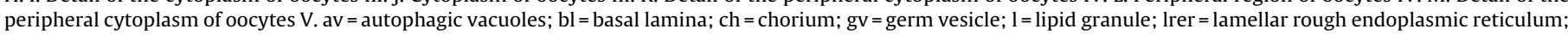
$\mathrm{m}=$ mitochondria; $\mathrm{mb}=$ myelinic bodies; $\mathrm{mv}=$ microvilli; $\mathrm{p}=$ proteic yolk granules; $\mathrm{pm}=$ plasma membrane; $\mathrm{v}=\mathrm{vacuoles}$

in the oocytes from this treatment group. The chorion is present in the peripheral region of the cell; however, in some regions, it is thinner and more electron dense than the one found in the oocytes IV from the previous groups (Fig. 4L,M).

The oocytes $\mathrm{V}$ present large and intact protein granules. However, other granules with different levels of electron density and numerous vacuoles surrounding the large granules and in the periphery of the cell are observed (Fig. 4N-Q). The lipid droplets are seldom observed. Although the chorion is present, showing subdivisions, it is not homogeneous and is sometimes thicker in the region surrounding the oocyte (Fig. $4 \mathrm{~N}-\mathrm{Q}$ ). 

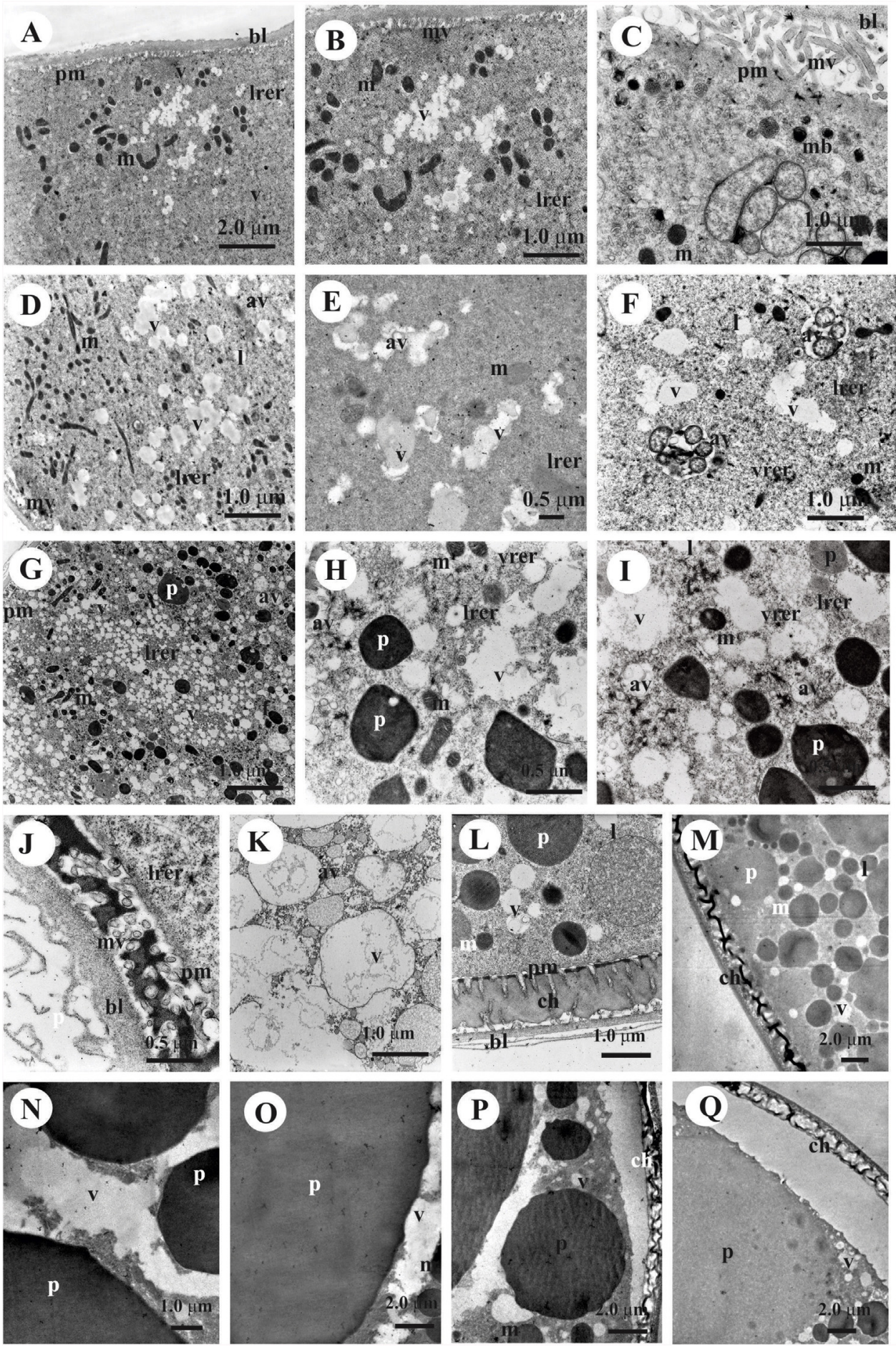

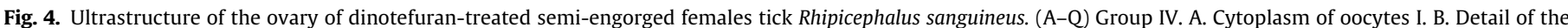

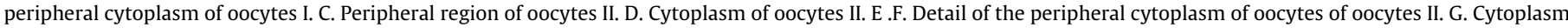

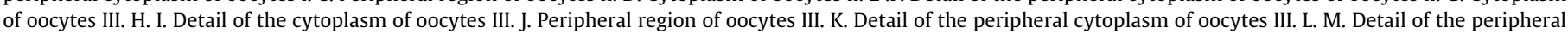

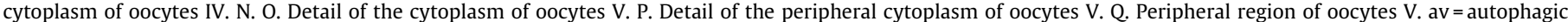

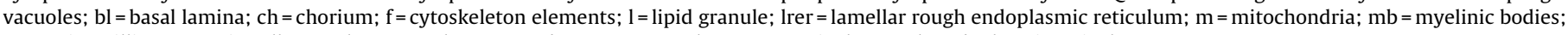
$\mathrm{mv}=$ microvilli; $\mathrm{p}=$ proteic yolk granules; $\mathrm{pm}=$ plasma membrane; $\mathrm{v}=$ vacuoles; vrer = vesicular rough endoplasmic reticulum.

\subsubsection{Midgut}

3.1.2.1. Control group. The midgut of the $R$. sanguineus semiengorged females from the control group is comprised of an epithelial wall supported by a basal lamina and a thin muscular tissue layer. The epithelial wall is pseudostratified and formed by generative and digestive cells (Fig. 5A,B).
The generative cells (Stem cells) are small, varying from cubic to prism-shaped and located on the basal membrane. The nucleus is large (occupying most part of the cytoplasm), central and round-shaped, with several pores in the membrane and dispersed chromatin (Fig. 5A,B). The cytoplasm does not show any evidence of digestive processes and contains a large number of organelles. It is full of well-developed lamellar rough endoplasmic reticulum, 

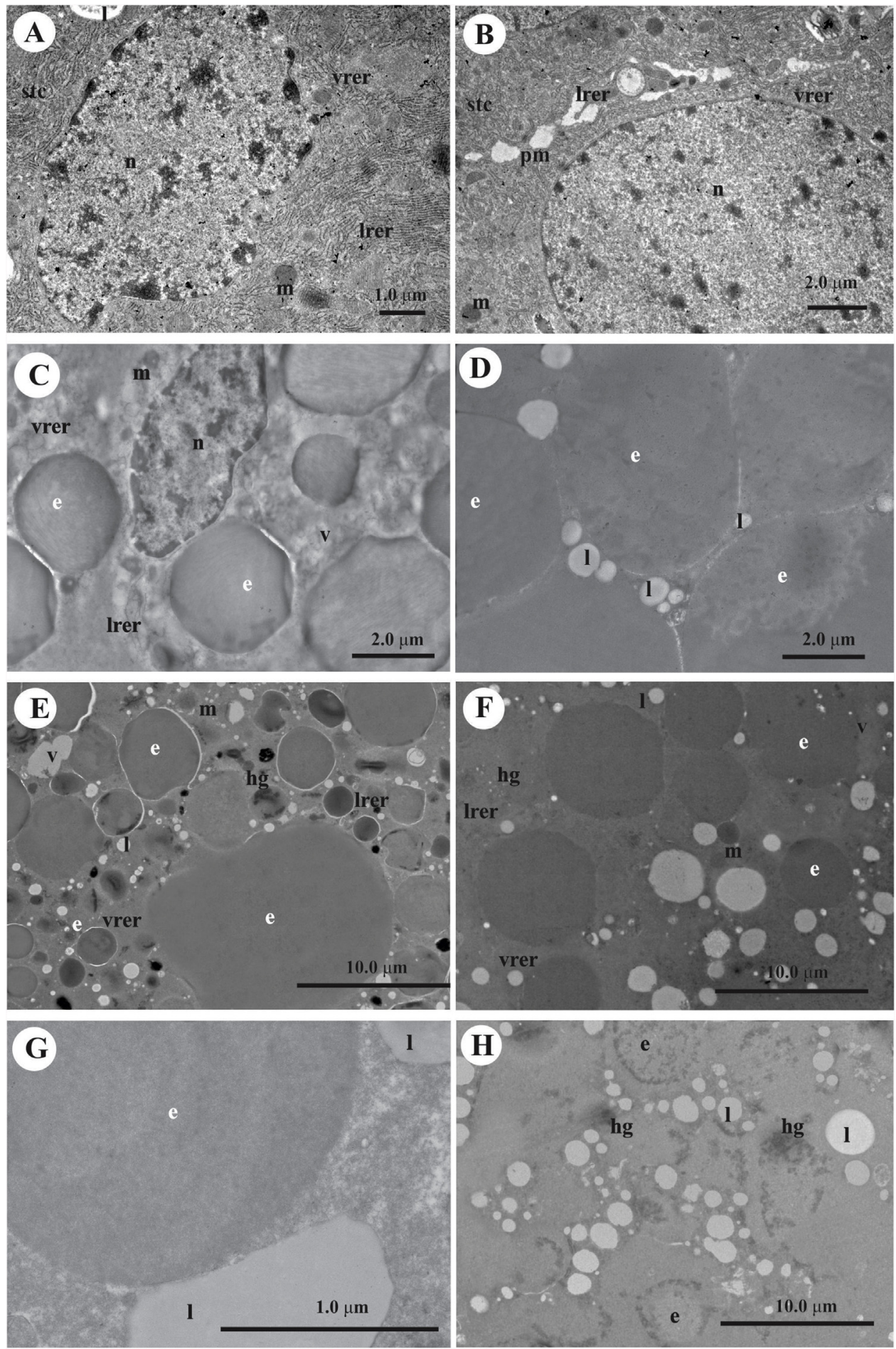

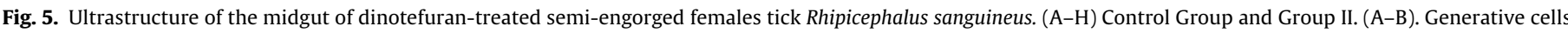

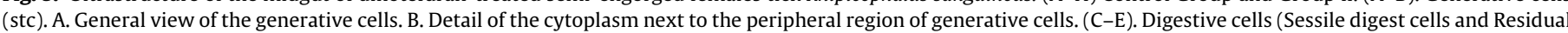

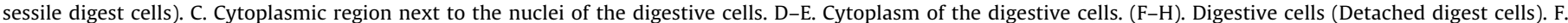

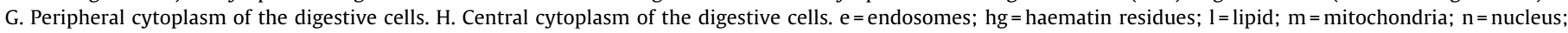
lrer = lamellar rough endoplasmic reticulum; $\mathrm{pm}=$ plasma membrane; vrer = vesicular rough endoplasmic reticulum; $\mathrm{v}=$ vacuoles.

mitochondria of different sizes and shapes and several ribosomes - both free, forming polyribosomes, and bound - adhered to the rough endoplasmic reticulum - and some small lipid droplets as well. (Fig. 5A,B).

The generative cells are covered by a plasma membrane. This membrane shows specializations such as invaginations, microvilli and some vesicles containing electron dense material towards the midgut lumen and among the adjacent cells (Fig. 5A,B).
The digestive cells are large and numerous (Fig. 5C-H). These cells undergo several developmental stages over their life cycle and during the tick engorgement processes. In the present study, the following digestive cell stages were identified: the sessile digest cells and/or the residual sessile digest cells, and the detached digest cells (Fig. 5C-H).

The first group of digestive cells (sessile digest cells and/or residual sessile digest cells) display a large nucleus, with marginalized 
heterochromatin internally distributed in the nuclear region. The nucleus is rarely detected due to presence of a large number of cytoplasmic structures, which modify its morphology or even cover it completely (Fig. 5C-E).

The cytoplasm displays numerous and large endosomes (with the blood ingested from the host during engorgement), several digestive vacuoles, as well as few highly electron dense residual hematin bodies (final product of the intracellular digestion) and small lipid droplets among these endosomes (Fig. 5C-E). Few mitochondria and lamellar/vesicular rough endoplasmic reticulum are observed in the region next to the nucleus and in the apical region of the cell as well (Fig. 5C-E).

The plasma membrane around the digestive cells shows few microvilli.

The second group of digestive cells (detached digest cells) comprises spherical and free cells distributed in the midgut lumen (Fig. 5F-H). The nucleus is frequently covered by endosomes. The cytoplasm shows smaller and less frequent endosomes in comparison with the first group of digestive cells, several digestive vacuoles and few highly electron dense residual hematin bodies (Fig. 5F-H). In addition, large lipid droplets (larger than the ones found in the first digestive cells) are observed, occupying mainly the region next to the nucleus (Fig. 5F-H). The plasma membrane limiting this cell show few microvilli.

The midgut lumen of the individuals from the control group contains blood, detached digest cells free in the lumen and the residues from the digestive processes, released by exocytosis and/or the lysis of digestive cells present in another digestion phase or life cycle, being incorporated to the fecal matter.

3.1.2.2. Group II. The midgut of the semi-engorged females subjected to $5000 \mathrm{ppm}$ of dinotefuran do not present ultra-structural alterations. The generative cells (stem cells), all the digestive cellssessile digest cells and/or the residual sessile digest cells and the detached digest cells, the muscular layer and the lumen are highly preserved and remain with the same characteristics found in the control group (group I) (Fig. 5A-H).

3.1.2.3. Group III. The midgut of the semi-engorged females from the group III, subjected to $6250 \mathrm{ppm}$ of dinotefuran showed significant alterations in comparison with the group control. These alterations occurred in the generative cells (stem cells) and in all stages of the digestive cells as well.

The generative cells (stem cells) have irregular shape, and show several deep folds in the plasma membrane. The microvilli are rarely observed and the basal lamina is thin and partially disrupted (Fig. 6A-C). The presence of vacuoles, including autophagic ones, is observed, in addition to myelin figures, mainly next to the periphery of the cell (Fig. $6 \mathrm{~A}-\mathrm{C}$ ). Regarding the organelles, the rough endoplasmic reticulum appears in lamellar and vesicular forms. The mitochondria display enlarged and altered cristae. Lipid droplets are rarely observed. Here, the nucleus shows several folds in the membrane and more condensed chromatin (Fig. 6A-C).

The digestive cells are less numerous. The nucleus and the membrane of the, sessile digest cells and/or residual sessile digest cells do not present evident alterations. Fewer endosomes and digestive vacuoles are found in the cytoplasm in comparison with the previous groups. These endosomes are smaller, frequently showing irregular shape and degenerated areas (Fig. 6D,E). The residual hematin bodies and lipid droplets are rarely found (Fig. 6D,E). The organelles, as mitochondria and the lamellar/vesicular rough endoplasmic reticulum are less frequently observed than in groups I and II (Fig. 6D,E). In these cells, disorganized areas emerge, showing vacuoles (Fig. 6D,E).

The detached digest cells are rarely observed. The nucleus and the plasma membrane were not affected. The cytoplasm shows fewer endosomes and digestive vacuoles in comparison with groups I, II and III. These endosomes are irregular and show degraded areas (Fig. 6F-H). The number of residual hematin bodies and lipid droplets is also smaller than in the other groups (Fig. 6F-H). The organelles, as mitochondria and the lamellar rough endoplasmic reticulum are less frequently observed. The mitochondria present enlarged cristae and the lamellar rough endoplasmic reticulum shows signs of vesiculation, justifying the large amount of vesicular rough endoplasmic reticulum found (Fig. $6 \mathrm{~F}-\mathrm{H}$ ). The peripheral cytoplasm show extensive disorganized and vacuolated areas, where myelin figures are observed (Fig. 6F-H).

3.1.2.4. Group IV. The semi-engorged females from the group IV show serious damages with evident cell disorganization. Such alterations occur in the generative (stem cells) and digestive cells.

The generative cells (stem cells) present very irregular shape, with several folds and distorted projections. The plasma membrane does not show microvilli; however, it limits an extensive region full of small spaces separating it from the basal lamina. This lamina is twisted, surrounding all this area (Fig. 7A,B). The intercellular space is enlarged and this region, limited by the membrane, also shows numerous small spaces (Fig. 7A,B).

The cytoplasm, becoming increasingly scarce, show vacuoles, autophagic vacuoles and myelin figures mainly in the basal region and next to the digestive cells (Fig. 7A,B). The number of organelles is significantly reduced. Little rough endoplasmic reticulum (both lamellar and vesicular) and few and small mitochondria with altered cristae are found (Fig. 7A,B). The lipid droplets are no longer observed (Fig. 7A,B).

As in the previous group, the nucleus membrane of these cells shows many folds and the chromatin is condensed (Fig. 7A,B).

The digestive cells are heavily affected. In the other groups (I, II and III,) it was possible to detect and distinguish several developmental stages of the digestive cells by their location and morphological characteristics (Fig. 7C-F). In the group IV, only the sessile digest cells and/or residual sessile digest cells were detected. These digestive cells present smaller and less frequent endosomes in comparison with the previous groups. These endosomes display a very irregular shape and areas with evidence of degeneration. Few digestive vacuoles and residual hematin bodies, in addition to the disappearance of lipid droplets in the cytoplasm are observed (Fig. 7C-F). In addition, the number of organelles is reduced, few mitochondria are detected and little lamellar rough endoplasmic reticulum occupies mainly the cytoplasm, mainly in the region next to the nucleus. The mitochondria show disorganized cristae and the vesiculation of the rough endoplasmic reticulum is observed, with the emergence of a large amount of vesicular rough endoplasmic reticulum (Fig. 7C-F). The presence of large disorganized areas is observed in the cytoplasm, in addition to myelin figures, cytoskeleton filaments and numerous vacuoles, including autophagic ones, with cell remains inside them, occupying the region next to the nucleus and the periphery of the cell as well (Fig. 7C-F)

There is a decrease in the number of microvilli in the plasma membrane, or even the disappearance of these specializations. Only the nucleus is preserved, showing similar characteristics to the ones found in the cells belonging to groups I, II and III (Fig. 7C-F).

\section{Discussion}

The $R$. sanguineus tick is a species of great medical and veterinary importance, transmitting several pathogens to the hosts, including the human being, and causing these hosts damages due to its spoliative action (Balashov, 1983; Wall and Shearer, 1997). This species is spread in urban areas and is completely adapted 

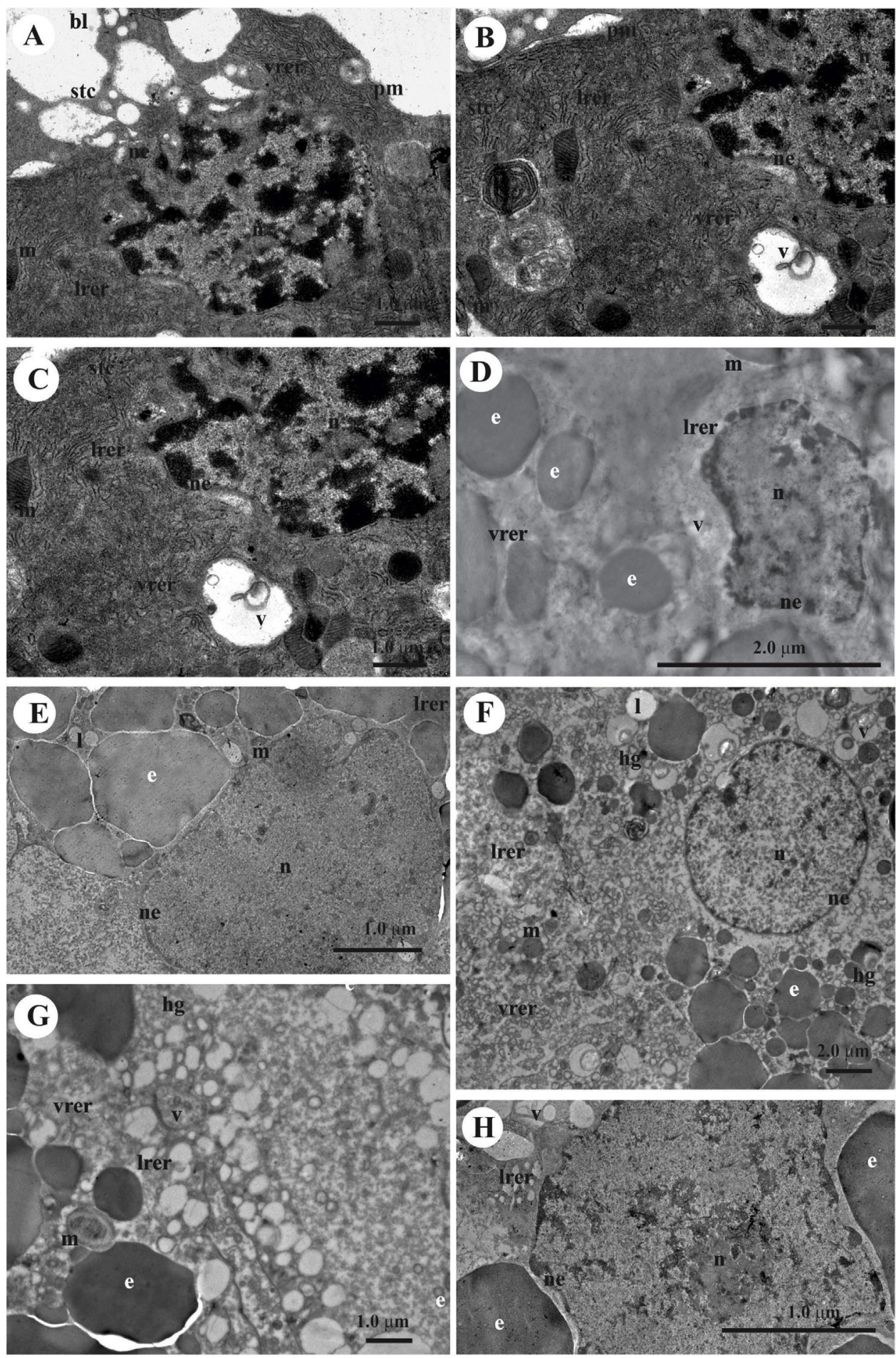

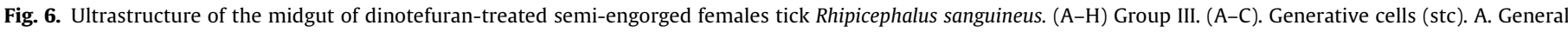

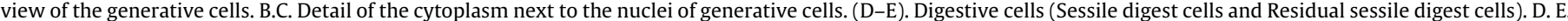

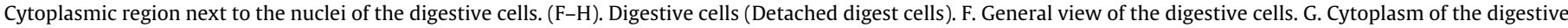

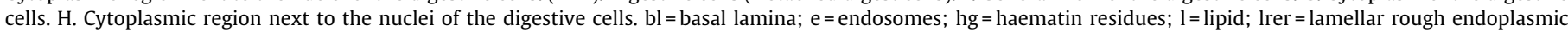
reticulum; $\mathrm{m}=$ mitochondria; $\mathrm{n}=$ nucleus, $\mathrm{ne}=$ nuclear envelope; $\mathrm{pm}=$ plasma membrane; vrer =vesicular rough endoplasmic reticulum; $\mathrm{v}=\mathrm{vacuoles}$.

to the hosts' environment, which significantly contributes to its worldwide distribution (Sonenshine and Roe, 2014).

The main method to control the $R$. sanguineus consists in the application of chemical acaricides on the hosts and the environment where they live. The indiscriminate use of these acaricides has resulted in the selection of more resistant populations of ticks. Another serious problem is the contamination of the environment and non-target organisms, which call for the development of new strategies and/or the improvement of the currently used control methods (Oliveira et al., 2013).

The neonicotinoids are substances with the potential to control pests, with high selectivity for the nicotinic acetylcholine receptors of the insects, low toxicity for the mammals, and excellent chemical and biological properties (Nauen and Bretschneider, 2002). The 

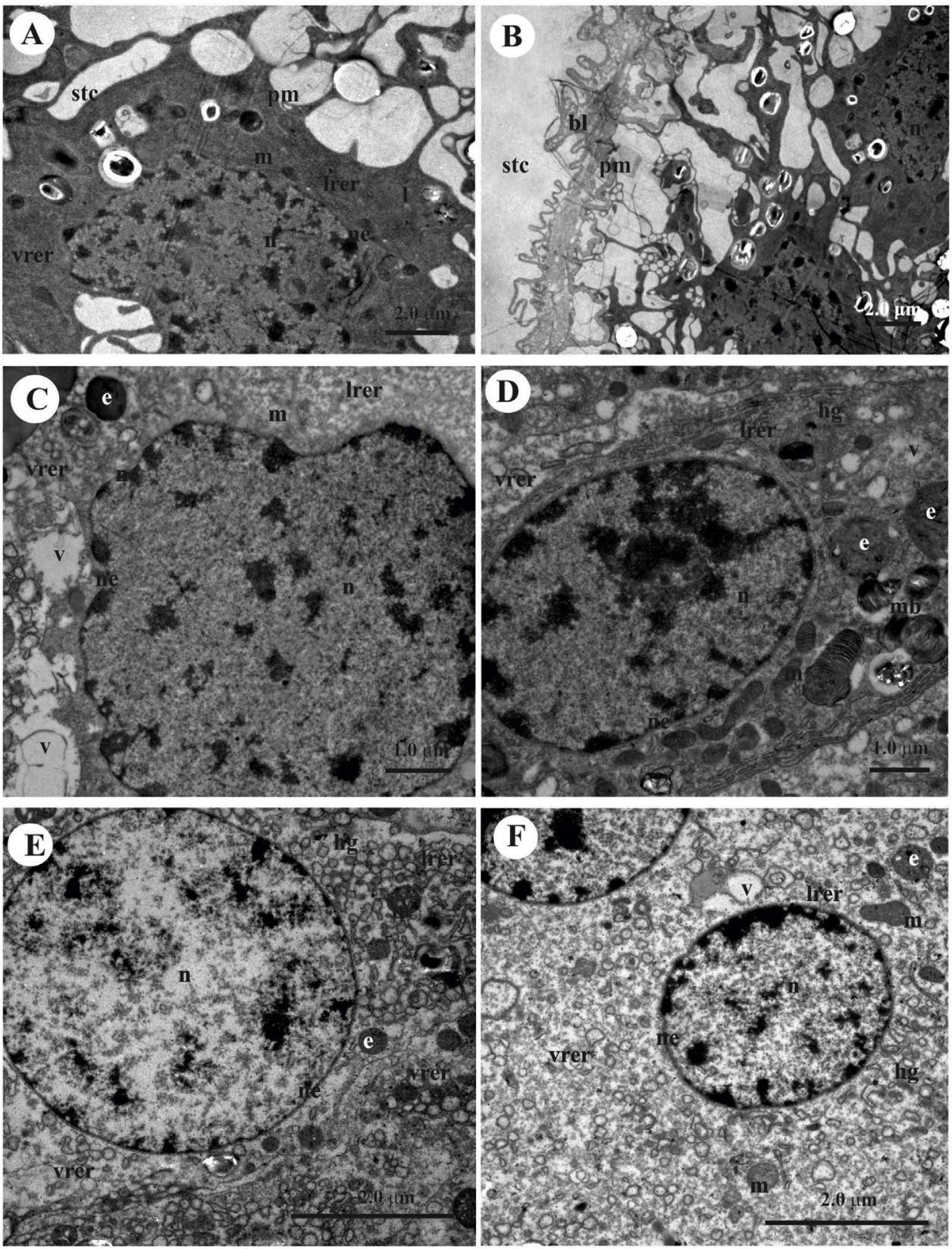

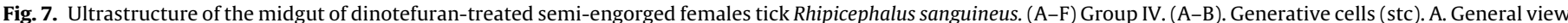

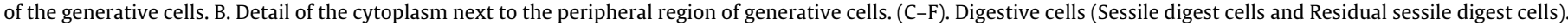

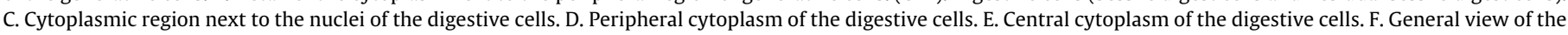

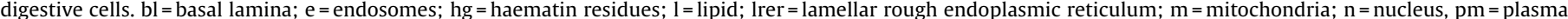
membrane; vrer = vesicular rough endoplasmic reticulum; v=vacuoles.

dinotefuran belongs to the third generation of neonicotinoids and can be considered one of the most important today (Wakita et al., 2003).

Considering this, the present study verified the effects of different concentrations of dinotefuran (active ingredient of the acaricide Protetor Pet ${ }^{\circledR}$ ) on the female germ cells (oocytes) and on the midgut epithelium of semi-engorged Rhipicephalus sanguineus ticks through an ultra-structural analysis, aiming to detect the occurrence of possible cell damages; i.e., analyze the interference in the genesis of new individuals and in the absorption of the food ingested from the host, providing fundamental information that will contribute to the development of new control methods and/or to the improvement of the currently used.
The individuals from the treatment groups II, III and IV were subjected to dinotefuran concentrations of $5000 \mathrm{ppm}, 6250 \mathrm{ppm}$ and $8334 \mathrm{ppm}$. The semi-engorged females from the different groups showed alterations in the ovaries and midgut cells when compared with those from group I (control). The main alterations were associated with the damaged cells structures, as the yolk granules, organelles and plasma membrane. Structures related to defense mechanisms, such as vacuoles, cytoskeleton filaments and myelin figures were found in the germ cells. In addition, damages in the midgut generative cells; alterations in the size of the digestive cells, the number of endosomes, digestive vacuoles, digestive residues, lipid droplets and organelles found in the cytoplasm of the digestive cells, and the presence of microvilli in the plasma membrane of the latter were observed. 
The ovary of the semi-engorged $R$. sanguineus females from the control group show characteristics already described by Oliveira et al. (2005). The ovary is comprised of an epithelial wall and a large number of oocytes in five developmental stages, attached to the wall through a pedicel, corroborating studies by Till (1961) for $R$. appendiculatus, Balashov (1983) for Hyalomma asiaticum, Denardi et al. (2004) for Amblyomma cajennense, Saito et al. (2005) for $B$. microplus. Only the species Amblyomma triste shows oocytes in four developmental stages (Oliveira et al., 2006).

The oocytes I and II of the females exposed to the dinotefuran concentrations of $5000 \mathrm{ppm}$ (group II), $6250 \mathrm{ppm}$ (group III) and $8334 \mathrm{ppm}$ (group IV) showed a gradual increase in the cytoplasmic vacuolation, demonstrating that, as the concentrations increased, more serious damages occurred in the cells. Considering these data and the application by immersion, it is possible to suggest that the dinotefuran would pass through the integument and the hemolymph, reach the ovary, penetrate the plasma membrane of these oocytes and damage the cell structures. These structures would be incorporated and lysed in vacuoles (Carvalho and Recco-Pimentel, 2012; Junqueira and Carneiro, 2013). These vacuoles would ensure the degradation of the damaged structures, maintaining the integrity of the cell and the viability of the oocyte, as observed by Oliveira et al. (2008, 2009), in $R$. sanguineus ticks treated with fipronil and by Roma et al. (2010) in R. sanguineus ticks treated with permethrin.

When compared with the oocytes II from the control group, the oocytes II from groupsII, III and IV, showed a decrease in the number of microvilli in the membrane. This situation could be interfering in the efficiency of the chemical to enter the oocyte, once the contact surface with the chemical is reduced (Oliveira et al., 2009). On the other hand, the incorporation of exogenous yolk elements would also be affected, justifying the reduction of lipid droplets observed in the oocytes II from group IV after the treatment. The occurrence of this process in the microvilli was also found by Roma et al. (2010) in $R$. sanguineus ticks subjected to permethrin and by Sampieri et al. (2012) in R. sanguineus ticks treated with ricinoleic acid from castor oil (Ricinus comunis).

The oocytes III subjected to $5000 \mathrm{ppm}$ of dinotefuran showed irregular protein granules with degenerated areas, probably due to the dinotefuran action, in addition to several vacuoles, autophagic vacuoles and myelin figures, possibly resulting from the autophagic processes caused by the chemical. Similar data were found by Lucantoni et al. (2006) for Anopheles stephensis Liston after exposure to Neem extract.

The oocytes III subjected to $6250 \mathrm{ppm}$, the same structures found in the oocyte III from the previous group were observed; however, in large number, which indicates the occurrence of heavier damages caused by this concentration of dinotefuran. In addition, the number of lipid droplets, mitochondria and the amount of lamellar rough endoplasmic reticulum decreased. The smaller number of cytoplasmic organelles allows us to suggest that the energy supply for all the cell activities (Alberts et al., 2010), including the conversion of vitellogenin to vitellin (production of the main yolk protein) (Sauer and Hair, 1986), as well as the synthesis of protein elements (endogenous production of yolk) (Oliveira et al., 2005) would be deficiently occurring, interfering in the development of these cells and even preventing the continuation of the vitellogenesis and the advancement to the following developmental stage. This energy loss was also found by Denardi et al. (2012) and Remedio et al. (2015a) in R. sanguineus ticks treated with neem extract and neem oil, respectively

The oocytes III subjected to $8334 \mathrm{ppm}$ of dinotefuran show more intense damages. Structures related with the occurrence of autophagic processes predominate in the cytoplasm of the oocytes treated with this concentration of dinotefuran: extensive vacuolation, irregular protein granules and degraded areas. These data indicate that several cell elements were damaged and need to be removed from the cell. This severe alterations would probably partially or totally harm the development of the cell, preventing it from reaching more advanced developmental stages (IV and V), and consequently affecting the female's fertility. Similar results were found by Oliveira et al. (2009) studying the oocytes III of $R$. sanguineus females exposed to fipronil.

As in the oocytes III from group III, the number of organelles and lipid droplets was reduced. However, the oocyte III from group IV showed a rough endoplasmic reticulum vesiculation. These data can be justified by the occurrence of the death process caused by dinotefuran, once the rough endoplasmic reticulum suffers dilation and vesiculation during this process, in addition to the separation and desegregation of the polysomes (Silva de Moraes and Bowen, 2000).

In addition, cytoskeleton elements were found in the oocytes III from group IV. These elements would occur with the purpose of isolating the functional regions from other already damaged ones, avoiding the proliferation of such damages (Jedrzejowska and Kubrakiewicz, 2007). Or even due to the permeability faults in the membrane, caused by the chemical (Kumar et al., 2013), which interfered in the cytoskeleton organization of these cells. Studies by Denardi et al. (2012) and Remedio et al. (2015b) also found disorganized cytoskeleton elements in $R$. sanguineus ticks exposed to the extract and oil of neem, respectively.

The periphery of the oocytes III from group IV, shows a decrease in the number of microvilli in comparison with the oocytes III from the previous groups, demonstrating that the incorporation of vitelline elements the hemolymph was also affected, justifying the decrease in the number and size of the yolk granules found in the cytoplasm of these cells.

Friesen et al. (2003), studying Amblyomma hebraeum ticks, reported that the chemical MK-243 (avermectin) inhibited the development of the oocytes by inhibiting the vitellogenin (main yolk protein) reception in the ovary. Consequently, the treated oocytes incorporated a small amount of vitellogenin, producing smaller and fewer yolk granules. This process probably occurred in the present study, once the oocytes III from group IV showed fewer yolk granules in comparison with the oocytes III from the previous groups. Similar data were found by Sayah et al. (1996) for the Labidura riparia insect subjected to Azadirachta indica.

The oocytes in less developed stages (I, II and III) suffered significant alterations, being more affected than those in more developed stages (IV and V). This can be occurring due to the absence of the chorion, a membrane that protects the eggs, very resistant and not totally deposited in these oocytes (Oliveira et al., 2005). Thus, without the presence of the chorion, the chemical passes only through the plasma membrane, which increases the efficacy of penetration. Reaching the interior of the cell, the chemical is able to cause reversible and irreversible damages, impairing the development of the oocytes and reducing the reproductive capacity of these ectoparasites, even preventing the formation of a new individual. This process was also found by Oliveira et al. (2009), Roma et al. (2010) and Vendramini et al. (2012) studying $R$. sanguineus ticks exposed to fipronil, permethrin and andiroba oil respectively.

Studies conducted by Friesen and Kaufman (2003), analyzing Amblyomma hebraeum, showed that the chemical cypermethrin, (pyrethroid) interrupted the vitellogenesis and development of the ovary, allowing the degeneration of the yolk present in the oocytes of the individuals treated, corroborating data obtained in the present study regarding the action of dinotefuran on the oocytes of $R$. sanguineus.

The oocytes in more advanced developmental stages (oocytes IV and V) were not seriously affected by the chemical. In group II, the oocytes IV and V were not affected; and in group III these oocytes suffered slight damages, mainly in the periphery of the 
cells. In group IV, the oocytes IV showed vacuoles among the large protein yolk granules, few lipid droplets, few mitochondria and little developed lamellar rough endoplasmic reticulum, in addition to a thinner chorion in some regions. The oocytes $\mathrm{V}$ display protein granules with different levels of electron density, numerous vacuoles, few lipid droplets and the chorion is not homogeneous in terms of thickness. These results might have occurred due to the action of dinotefuran. Although the deposition of the chorion (Oliveira et al., 2005), highly resistant membrane responsible for preserving and protecting the future embryo (Denardi et al., 2004) has already occurred in these cells, it is not sufficient to prevent the chemical from entering and causing damages, once alterations were observed in the cytoplasm of both oocytes. However, the chorion certainly decreases the efficiency of the chemical, since it represents a barrier to be crossed. Studies by Oliveira et al. (2009), Roma et al. (2010) and Vendramini et al. (2012) on $R$. sanguineus ticks subjected to fipronil, permethrin and andiroba, respectively, corroborate these data.

The midgut is another organ studied aiming to understand the action of dinotefuran. The midgut of semi-engorged $R$. sanguineus females from the control group displayed an epithelial wall comprised of different types of cells, supported by a basal membrane and a thin layer of muscular tissue. These data corroborate Till (1961), Balashov (1983), Agbede and Kemp (1985), Koh et al. (1991), Sonenshine and Roe (2014), Agyei and Runham (1995) and Harrison and Foelix (1999), who studied other species of ticks.

The midgut epithelial wall of the $R$. sanguineus female is comprised of generative and digestive cells (Remedio et al., 2013). The generative cells (Stem cells) are small and totally located on the basal membrane (Agbede and Kemp, 1985; Agyei and Runham, 1995; Koh et al., 1991; Walker and Fletcher, 1987). These cells are pluripotent, with high proliferative capacity and responsible for forming the other types of cells present in the midgut (Agbede and Kemp, 1985; Agyei and Runham, 1995; Walker and Fletcher, 1987). In the present study, as these cells do not show any evidence of digestive processes and contain a large number of organelles, they are probably performing this function.

The midgut of the semi-engorged $R$. sanguineus females also showed digestive cells. The sessile digest cells and/or residual sessile digest cells display numerous and large endosomes, several digestive vacuoles, few residual hematin bodies, small lipid droplets, few mitochondria, little developed lamellar/vesicular rough endoplasmic reticulum, and the plasma membrane with few microvilli. The detached digest cells are spherical and free in the midgut lumen, the cytoplasm shows smaller and less frequent endosomes, several digestive vacuoles, few residual hematin bodies, large lipid droplets and plasma membrane with few microvilli. Similar results were found by Agbede and Kemp (1985), Walker and Fletcher (1987) and Agyei and Runham (1995) for other species of ticks.

There are excellent descriptions about the morphology, histology and physiology of the tick midgut in the literature. Further information is found in the studies by Agbede and Kemp (1985), Walker and Fletcher (1987), Koh et al. (1991), Sonenshine and Roe (2014), Agyei and Runham (1995), Harrison and Foelix (1999) and Remedio et al. (2013).

The midgut of the semi-engorged females subjected to 5000 ppm of dinotefuran did not show morphological alterations, which indicates that in this concentration the chemical does not cause harmful modification to the organ. In the females exposed to $6250 \mathrm{ppm}$ of dinotefuran, alterations were observed in the generative cells (stem cells) and in all stages of the digestive cells, demonstrating that the dinotefuran started to affect these cells. The generative cells (stem cells) showed irregular morphology and partially disrupted basal membrane, as well as vacuoles, autophagic vacuoles, myelin figures, lamellar and vesicular rough endoplasmic reticulum and enlarged mitochondria with altered cristae throughout the cytoplasm. These results can be justified by the action of dinotefuran, damaging the cells and decreasing their capacity of proliferation and cell differentiation (Agbede and Kemp, 1985; Walker and Fletcher, 1987). These functions are needed to replace the worn-out cells that are lost during the digestive process and renovate all the midgut cells (Agbede and Kemp, 1985; Agyei and Runham, 1995; Harrison and Foelix, 1999; Walker and Fletcher, 1987). Damaged cells can originate other faulty or imperfect cells (Barreto et al., 2006). Processes of reduction and damage in generative cells were described by Correia et al. (2009) Spodoptera frugiperda caterpillars treated with neem.

All the digestive cells, the sessile digest cells and residual sessile digest cells - and detached digest cells showed cytoplasmic alterations, which allows us to infer that the chemical dinotefuran is really causing damages to the digestive cells of the treated animals. Due to the lesions occurred, the efficiency of the digestive processes would be affected, interfering in the acquisition of the blood ingested from the host during engorgement (Agbede and Kemp, 1985; Agyei and Runham, 1995; Koh et al., 1991; Walker and Fletcher, 1987); the blood cell hemolysis in the digestive vacuoles (Sonenshine and Roe, 2014); the formation of digestive residues (final product of the intracellular digestion) (Agbede and Kemp, 1985; Agyei and Runham, 1995; Koh et al., 1991); and the release of nutrients after the digestion processes (Sonenshine and Roe, 2014).

The digestive cells sessile digest cells and the residual sessile digest cells of the individuals from group III show smaller and less frequent endosomes, with irregular shape and degenerated areas, in addition to fewer digestive vacuoles, hematin residual bodies, lipid droplets and organelles in comparison with the ones from control group and group II. The digestive cells, detached digest cells, were seldom observed. All the alterations observed in the sessile digest cells and the residual sessile digest cells occurred here. These data indicate that the digestive processes are not occurring adequately, due to the interference of the dinotefuran. The chemical would probably be damaging any structure associated with the blood acquisition, and consequently reducing and impairing the absorption of the blood elements ingested and the formation of endosomes. Consequently, the other processes involved in the digestion would also be affected: decrease in the number of digestive vacuoles necessary for the lysis of the small amount of blood ingested (intracellular digestion) (Harrison and Foelix, 1999; Sonenshine and Roe, 2014) and in the number of digestive residues formed and gradually accumulated in the interior of the cells as well. Likewise, the nutritious elements of the blood would be converted into lipids and stored after digestion (Sonenshine and Roe, 2014). The nutritious elements released and necessary for the nutrition of the ectoparasite (Sonenshine and Roe, 2014) were also reduced, affecting the organ, the other systems (once they function together), and eventually the whole individual. Studies by Araujo (2012) also detected such alterations in the midgut of Rhipicephalus sanguineus ticks treated with selamectin.

Sonenshine and Roe (2014), reported that the ticks' survival strategies over fasting periods waiting for a host is associated with the storage of large amounts of blood during engorgement and the slow digestion after this process. Harrison and Foelix (1999) complements that in ixodidae ticks this process occurs just once in each stage of the life cycle. In the present study, a reduction in the blood elements acquired (formed endosomes) was observed, demonstrating that the ticks treated did not accumulate the same amount of blood, the only source of nutrients. Thus, it can be inferred that the animals treated with dinotefuran would not have the same success as a parasite. Similar data were found by Oliveira et al. (2013) 
for $R$. sanguineus ticks exposed to the arthropod growth regulator (AGR) fluazuron.

The cells from the group IV exposed to $8334 \mathrm{ppm}$ of dinotefuran showed more significant alterations in comparison with those from the previous group, demonstrating the effects of dinotefuran are dose-dependent; i.e., the higher the concentration, the heavier the damages caused in treated individuals. In this group, the alterations occurred in the generative (stem cells) and digestive cells as well. The generative cells (stem cells) display a very irregular shape, once their membrane formed numerous folds and distorted projections, and the membrane limited an extensive region full of small spaces separating it from the basal lamina. Therefore, the basal membrane was almost completely detached from the basal lamina, probably due to some fault in the cell-cell/cell-matrix interaction, causing the destruction of the adhesion complexes and consequent loss of adhesion. The detachment of the cells from the basal lamina was reported by Valotto et al. (2011) in Aedes aegypti larvae subjected to the catequic tannin isolated from the plant Magonia pubesncens and by Ghribi et al. (2012) in Spodoptera littoralis after exposure to biosurfactants.

In the generative cells from the group IV, an increase in the intracellular space and in the number of vacuoles, autophagic vacuoles and myelin figures was observed, suggesting that these alterations were caused by the chemical dinotefuran. These cells would have been damaged and lysed in vacuoles (Carvalho and Recco-Pimentel, 2012; Junqueira and Carneiro, 2013). The emergence of these structures are evidence of cellular degeneration (Scudeler and Santos, 2013). Similar results were found by Ghribi et al. (2012) studying insects treated with biosurfactantss and by Scudeler et al. (2014) in insects treated with neem oil (Azadirachta indica). As the generative cells are responsible for the production of new digestive cells for the digestion process (Agbede and Kemp, 1985; Agyei and Runham, 1995; Harrison and Foelix, 1999; Walker and Fletcher, 1987) and here these cells showed evidence of cell death after the treatment, the mitotic divisions would probably not be occurring, or would be deficiently occurring, inhibiting the adequate replacement of the cells released from the basal membrane during digestion and of the worn-out digestive cells. Thus, the entire digestive process would be inhibited, preventing the acquisition of blood nutrients, important for the nutrition of the ectoparasite, consequently affecting its development and reproductive capacity.

The sessile digest cells and the residual sessile digest cells of the semi-engorged females from group IV displayed large lesions, confirming that the dinotefuran concentration of $8334 \mathrm{ppm}$ causes the most serious damages in the cells of individuals treated. The number of damaged structures increased significantly in comparison with the digestive cells of the individuals from the group III: irregular endosomes, digestive vacuoles, residual hematin bodies and lipid droplets, still smaller and less numerous. This could be occurring due to the action of the chemical dinotefuran, affecting several cell components, preventing the normal functioning of the cells, and impairing the metabolism of the cell, the organ and the viability of the individual itself. This process was described by Oliveira et al. (2014) for Rhipicephalus sanguineus ticks exposed to the chemical fluazuron.

In addition, the disorganization of the mitochondria cristae and the vesiculation of the rough endoplasmic reticulum were also detected in these cells. The alterations in the mitochondria would have occurred due to the increase of $\mathrm{Ca} 2+$ and/or cellular stress, interfering in the structure of the inner mitochondrial membrane, making it permeable (Proskuryakov et al., 2002). Consequently, the efficiency of the respiratory metabolism is being affected; i.e., mitochondrial dysfunctions take place, decreasing or completely interrupting the production of ATP, and eventually inducing cell death (Proskuryakov et al., 2002). Studies by Qi et al.
(2011) also found mitochondrial modifications in Mythimna separata after treatment with insecticides.

According to Silva de Moraes and Bowen (2000), Qi et al. (2011), Scudeler and Santos (2013) and Scudeler et al. (2016), the emergence of the vesicular rough endoplasmic reticulum is related with the dilation and fragmentation of the lamellar rough endoplasmic reticulum during the cell death process. In the present study, this vesiculation process might be occurring in the digestive cells of the individuals from group IV after the treatment. As the mitochondria and the rough reticulum play a fundamental role in the cell functioning and were affected here, the digestive cell abnormal metabolism was demonstrated in the females from group IV.

The digestive cells of the individuals from group IV showed large disorganized areas and increase in the number of vacuoles, myelin figures and autophagic vacuoles in comparison with the group III, demonstrating that the dinotefuran concentration of 8334 ppm caused heavy damages to these cells. Consequently, the structures responsible for the autophagic processes would become more numerous, in an attempt to eliminate the damaged elements. The occurrence of this process has also been reported by Barreto et al. (2006), in A. aegypti larvae after exposure to ethanolic extract of Sapindus saponaria Lin (Sapindaceae), Valotto et al. (2011), in A. aegpti larvae subjected to the natural compound obtained from Magonia pubescens (Sapindaceae) and by Scudeler and Santos (2013), in Ceraeochrysa claveri larvae treated with Neem oil.

On the other hand, the significant emergence of cytoskeleton filaments in the digestive cells subjected to $8334 \mathrm{ppm}$ of dinotefuran can be justified by the depolymerization of actin that disorganized the cytoskeleton (Scudeler and Santos, 2013), or by the cell defensive reaction, trying to avoid the contact between the stillfunctioning areas and other portions of damaged cells, so that less damage would be caused by the chemical; i.e, avoiding the damage propagation (Jedrzejowska and Kubrakiewicz, 2007).

Finally, the plasma membrane of the digestive cells from group IV showed a decrease in the number of microvilli, or even the complete disappearance of these structures. This could be occurring to decrease contact with the chemical, interrupting its passage from the lumen to the cell interior and protecting the cell from lesions (Oliveira et al., 2009). Similar data were found by Alves et al. (2010) for Culex quinquefasciatus larvae treated with different insecticides and by Scudeler and Santos (2013) for Ceraeochrysa claveri larvae treated with neem oil.

The detached digest cells were not detected in the individuals from group IV. This result allows us to infer that the digestive cells are not passing through intermediate stages over the engorgement process in order to digest the blood elements completely (Agbede and Kemp, 1985; Agyei and Runham, 1995; Harrison and Foelix, 1999). As a result, the blood elements would be partially or even not digested, which would affect the nutrition of the treated ectoparasites, impairing their development and reproductive performance, possibly leading them to death.

Studies conducted by Tomizawa and Casida (2005) found that the dinotefuran acts on the central nervous system of the individuals exposed. This chemical binds agonistically to the nicotinic acetylcholine postsynaptic receptors; however, the enzyme acetylcholinesterase is not able to degrade the dinotefuran, that remains bound to the receptor and keeps the $\mathrm{Na}+$ ions channels open and moving towards the interior of the cell, depolarizing it and causing the prolonged, continuous and uncontrolled nervous impulse (Kagabu, 1997; Uneme et al., 1999; Wakita, 2011; Wakita et al., $2005,2003)$. The present study demonstrated that, in addition to the neurotoxic effects, the dinotefuran can also affect other systems of the arthropods. 


\section{Conclusion}

Thus, it was verified that the dinotefuran is able to damage the midgut and ovary cells of semi-engorged $R$. sanguineus female ticks. In the midgut, the concentrations applied damaged both the generative cells (fundamental for cell production and replacement) and the digestive cells (responsible for the blood acquisition, hemolysis, formation of digestive residues and release of nutrients), which demonstrates that the digestive processes are deficient and the nutrition is compromised, possibly leading the individual to death. As for the ovary, these concentrations damaged mainly the oocytes in the initial stages of development (I, II and III), which would suppress vitellogenesis and, therefore, the advancement for the following developmental stages, reducing the fertility of the female. Even if the vitellogenesis proceeds and the oocyte is fertilized, the dinotefuran can affect the viability of the embryos; and, consequently, of the species.

\section{Acknowledgments}

We would like to thank to PNPD for financial support and CNPQ academic career research fellowship to G.H. Bechara and M.I. Camargo-Mathias.

\section{References}

Agbede, R., Kemp, D., 1985. Digestion in the cattle-tick Boophilus microplus: light microscope study of the gut cells in nymphs and females. Int. J. Parasitol. 15 147-157, http://dx.doi.org/10.1016/0020-7519(85)90080-3.

Agyei, A., Runham, N., 1995. Studies on the morphological changes in the midguts of two ixodid tick species Boophilus microplus and Rhipicephalus appediculatus during digestion of the blood meal. Int. J. Parasitol. 25, 55-62, http://dx.doi. org/10.1016/0020-7519(94)00114-4

Alberts, B., Johnson, A., Lewis, J., Raff, M., Roberts, K., Walter, P., 2010. Biologia Molecular Da célula 5th Ed. Artmed, Porto Alegre.

Alves, S.N., Serrão, J.E., Melo, A.L., 2010. Alterations in the fat body and midgut of Culex quinquefasciatus larvae following exposure to different insecticides. Micron 41,592-597, http://dx.doi.org/10.1016/j.micron.2010.04.004.

Araujo, A.M., 2012. Alterações histológicas no intestino de fêmeas de carrapatos Rhipicephalus sanguineus (Latreille, 1806) (Acari: Ixodidae) expostas a diferentes concentrações de selamectina. Universidade Estadual Paulista.

Balashov, Y., 1983. The female reproductive system. In: Balashov, Y.S. (Ed.), An Atlas of Ixodid Tick Ultrastructure. Entomological Society of America, Russia, pp. 98-128.

Barreto, C.F., Cavasin, G.M., Silva, H.H.G., Silva, I.G., 2006. Estudo das alterações morfo-histológicas em larvas de Aedes aegypti (Diptera, Culicidae) submetidas ao extrato bruto etanólico de Sapindus saponaria Lin (Sapindaceae). Rev. Patol. Trop. 35, 37-57.

Bechara, G.J.S.M., Ferreira, B., Garcia, M., 1995. Rhipicephalus sanguineus tick in Brazil: feeding and reproductive aspects under laboratorial. Braz. J. Vet. Parasitol. Cond. 4, 61-66.

Carvalho, H.F., Recco-Pimentel, S.M., 2012. A Célula, 3a ed. Editora Manole, São Paulo.

Correia, A.A., Wanderley-Teixeira, V., Teixeira, Á.A.C., Oliveira, J.V., Torres, de, 2009 Morfologia do canal alimentar de lagartas de Spodoptera frugiperda (J E Smith) (Lepidoptera: Noctuidae) alimentadas com folhas tratadas com nim. Neotrop. Entomol. 38, 83-91, http://dx.doi.org/10.1590/S1519-566x2009000100008.

Coutinho, M.T.Z., Bueno, L.L., Sterzik, A., Fujiwara, R.T., Botelho, J.R., De Maria, M., Genaro, O., Linardi, P.M., 2005. Participation of Rhipicephalus sanguineus (Acari: Ixodidae) in the epidemiology of canine visceral leishmaniasis. Vet. Parasitol. 128, 149-155, http://dx.doi.org/10.1016/j.vetpar.2004.11.011.

Craig, T., 1990. Infectious Diseases of the Dog and Cat. W.B. Saunders Co, Philadelphia.

Crampton, A., Baxter, G., Barker, S., 1999. Identification and characterisation of a cytochrome P450 gene and processed pseudogene from an arachnid: the cattle tick, Boophilus microplus. Insect Biochem. Mol. Biol. 29, 377-384, http://dx. doi.org/10.1016/s0965-1748(99)00013-2.

Denardi, S.E., Bechara, G.H., Oliveira, P.R., Nunes, de, Saito, E.T., Mathias, K.C., 2004 Morphological characterization of the ovary and vitellogenesis dynamics in the tick Amblyomma cajennense (Acari: Ixodidae). Vet. Parasitol. 125, 379-395, http://dx.doi.org/10.1016/j.vetpar.2004.07.015.

Denardi, S.E., Bechara, G.H., de Oliveira, P.R., Mathias, M.I.C., 2012. Ultrastructural analysis of the oocytes of female Rhipicephalus sanguineus (Latreille, 1806) (Acari: Ixodidae) ticks subjected to the action of Azadirachta indica A. Juss (neem). Ultrastruct. Pathol. 36, 56-67, http://dx.doi.org/10.3109/01913123. 2011.588819 .
Dryden, M.W., Payne, P.A., Vicki, S.R., Kobuszewski, D., 2011. Efficacy of topically applied dinotefuran formulations an orally administered spinosad tablets against the KS1 Flea strain infesting dogs. Int. J. Appl. Res. Vet. Med. 9, 124-129.

EPA, O. of P., 2009. Pesticides and Toxic Substances: Pesticide Fact Sheet Dinotefuran. EPA PC Code 044312 [WWW Document]. URL www.epa.gov/ opprd001/factsheets/dinotefuran.pdf (Accessed 3.1.09).

French, T.W., Harvey, J.W., 1983. Serologic diagnosis of infectious cyclic thrombocytopenia in dogs using an indirect fluorescent antibody test. Am. J. Vet. Res. 44, 2407-2411.

Friesen, K.J., Kaufman, W.R., 2003. Cypermethrin inhibits egg development in the ixodid tick, Amblyomma hebraeum. Pestic. Biochem. Physiol. 76, 25-35, http:// dx.doi.org/10.1016/S0048-3575(03)00032-4.

Friesen, K.J., Suri, R., Kaufman, W.R., 2003. Effects of the avermectin, MK-243, on ovary development and salivary gland degeneration in the ixodid tick, Amblyomma hebraeum. Pestic. Biochem. Physiol. 76, 82-90, http://dx.doi.org/ 10.1016/S0048-3575(03)00070-1.

Ghribi, D., Abdelkefi-Mesrati, L., Boukedi, H., Elleuch, M., Ellouze-Chaabouni, S., Tounsi, S., 2012. The impact of the Bacillus subtilis SPB1 biosurfactant on the midgut histology of Spodoptera littoralis (Lepidoptera: Noctuidae) and determination of its putative receptor. J. Invertebr. Pathol. 109, 183-186, http://dx.doi.org/10.1016/j.jip.2011.10.014.

González, A., Castro, D., del, C., González, S., 2004. Ectoparasitic species fromCanis familiaris (Linné) in buenos aires province, Argentina. Vet. Parasitol. 120, 123-129, http://dx.doi.org/10.1016/j.vetpar.2003.12.001.

Harrison, W., Foelix, R., 1999. Chelicerata: arthropoda. In: Harrison, W., Foelix, R. (Eds.), Microscopic Anatomy of Invertebrates. Wiley-Liss New York, NY.

Jedrzejowska, I., Kubrakiewicz, J., 2007. The Balbiani body in the oocytes of a common cellar spider, Pholcus phalangioides (Araneae: Pholcidae). Arthropod. Struct. Dev. 36, 317-326, http://dx.doi.org/10.1016/j.asd.2007.01.004.

Junqueira, L.C., Carneiro, J., 2013. Histologia Básica. Guanabara Koogan, Rio de Janeiro.

Kagabu, S., 1997. Chloronicotinyl insecticides - discovery, application and future perspective. Rev. Toxicol. 1, 75-129.

Koh, K., Mori, T., Shiraishi, S., Uchida, T.A., 1991. Ultrastructural changes of the midgut epithelial cells in feeding and moulting nymphs of the tick Haemaphysalis longicornis. Int. J. Parasitol. 21, 23-36, 0020-7519(91)90117-P [pii].

Kumar, S., Pandey, A.K., Kumar, S., Pandey, A.K., 2013. Chemistry and biological activities of flavonoids: an overview. Sci. World J. 2013, 1-16, http://dx.doi. org/10.1155/2013/162750.

Labruna, M., Pereira, M., 2001. Carrapato em Cães no Brasil. Clín. Vet. 30, 24-32.

Lucantoni, L., Giusti, F., Cristofaro, M., Pasqualini, L., Esposito, F., Lupetti, P., Habluetzel, A., 2006. Effects of a neem extract on blood feeding, oviposition and oocyte ultrastructure in Anopheles stephensi Liston (Diptera: Culicidae). Tissue Cell 38, 361-371, http://dx.doi.org/10.1016/j.tice.2006.08.005.

Merle, C., Sotto, A., Barbuat, C., Jourdan, J., 1998. Disease course of mediterranean spotted fever: remark on 16 cases. 7e Colloque Sur Le Controle Epidemiologique Des Maladies Infectieuses, 400-401.

Nauen, R., Bretschneider, T., 2002. New modes of action of insecticides. Pestic. Outlook 13, 241-245, http://dx.doi.org/10.1039/b211171n.

Nolan, J., 1985. Mechanisms of resistance to chemicals in arthropod parasites of veterinary importance. Vet. Parasitol. 18, 155-166, http://dx.doi.org/10.1016 0304-4017(85)90064-0.

Oliveira, P.R., Bechara, G.H., Denardi, S.E., Nunes, E.T., Camargo-Mathias, M.I., 2005. Morphological characterization of the ovary and oocytes vitellogenesis of the tick Rhipicephalus sanguineus (Latreille, 1806) (Acari: Ixodidae). Exp. Parasitol. 110, 146-156, http://dx.doi.org/10.1016/j.exppara.2004.12.016.

Oliveira, P.R., Camargo-Mathias, M.I., Bechara, G.H., 2006. Amblyomma triste (Koch, 1844) (Acari: Ixodidae): morphological description of the ovary and of vitellogenesis. Exp. Parasitol. 113, 179-185, http://dx.doi.org/10.1016/j. exppara.2006.01.012.

Oliveira, P.R., Bechara, G.H., Camargo-Mathias, M.I., 2008. Evaluation of cytotoxic effects of fipronil on ovaries of semi-engorged Rhipicephalus sanguineus (Latreille, 1806) (Acari: Ixodidae) tick female. Food Chem. Toxicol. 46, 2459-2465, http://dx.doi.org/10.1016/j.fct.2008.03.034.

Oliveira, P.R., De Bechara, G.H., Morales, M.A.M., Mathias, M.I.C., 2009. Action of the chemical agent fipronil on the reproductive process of semi-engorged females of the tick Rhipicephalus sanguineus (Latreille, 1806) (Acari: Ixodidae). Ultrastructural evaluation of ovary cells. Ultrastructural evaluation of ovary cells. Food Chem. Toxicol. 47, 1255-1264, http://dx.doi.org/10.1016/j.fct.2009. 02.019.

Oliveira, P.R., Calligaris, I.B., Roma, G.C., Bechara, G.H., Camargo-Mathias, M.I., 2013. Fluazuron-induced morphophysiological changes in the cuticle formation and midgut of Rhipicephalus sanguineus Latreille, 1806 (Acari: Ixodidae) nymphs. Parasitol. Res. 112, 45-58, http://dx.doi.org/10.1007/s00436-012-3103-7.

Oliveira, P.R., Calligaris, I.B., Bechara, G.H., Mathias, M.I.C., 2014. Rhipicephalus sanguineus sensu lato (Acari: Ixodidae) nymphs: an ultrastructural study of the integument and midgut. Ticks Tick. Borne. Dis. 5, 834-840, http://dx.doi.org/ 10.1016/j.ttbdis.2013.11.010.

Proskuryakov, S.Y., Gabai, V.L., Konoplyannikov, A.G., 2002. Necrosis is an active and controlled form of programmed cell death. Biochem. Biokhimîa 67 , 387-408.

Pruett, J.H., 1999. Immunological control of arthropod ectoparasites - a review. Int. J. Parasitol. 29, 25-32, http://dx.doi.org/10.1016/S0020-7519(98)00172-6.

Qi, Z., Shi, B., Hu, Z., Zhang, Y., Wu, W., 2011. Ultrastructural effects of Celangulin V on midgut cells of the oriental armyworm, Mythimna separata walker 
(Lepidoptera: Noctuidae). Ecotoxicol. Environ. Saf. 74, 439-444, http://dx.doi. org/10.1016/j.ecoenv.2010.10.004.

Remedio, R.N., Sampieri, B.R., Vendramini, M.C.R., Souza, N.M., Anholeto, L.A., Denardo, T.A.G.B., Camargo-Mathias, M.I., 2013. Morphology of the midgut of Rhipicephalus sanguineus (Latreille, 1806) (Acari: Ixodidae) adult ticks in different feeding stages. Parasitol. Res. 112, 415-425, http://dx.doi.org/10 1007/s00436-012-3153-X.

Remedio, R.N., Nunes, P.H., Anholeto, L.A., Oliveira, P.R., Camargo-Mathias, M.I., 2015a. Morphological effects of neem (Azadirachta indica A. Juss) seed oil with known azadirachtin concentrations on the oocytes of semi-engorged Rhipicephalus sanguineus ticks (Acari: Ixodidae). Parasitol. Res. 114, 431-444, http://dx.doi.org/10.1007/s00436-014-4200-6.

Remedio, R.N., Nunes, P.H., Anholeto, L.A., Oliveira, P.R., Camargo-Mathias, M.I., 2015b. Morphological effects of neem (Azadirachta indica A. Juss) seed oil with known azadirachtin concentrations on the oocytes of semi-engorged Rhipicephalus sanguineus ticks (Acari: Ixodidae). Parasitol. Res. 114, 431-444, http://dx.doi.org/10.1007/s00436-014-4200-6.

Roma, G.C., Furquim, K.C.S., Bechara, G.H., Camargo-Mathias, M.I. 2010 Permethrin-induced morphological changes in oocytes of Rhipicephalus sanguineus (Acari: Ixodidae) semi-engorged females. Food Chem. Toxicol. 48, 825-830, http://dx.doi.org/10.1016/j.fct.2009.12.016.

Saito, K.C., Bechara, G.H., Nunes, E.T., Oliveira, P.R., Denardi, S.E., Camargo-Mathias, M.I., 2005. Morphological, histological, and ultrastructural studies of the ovary of the cattle-tick Boophilus microplus (Canestrini, 1887) (Acari: Ixodidae). Vet. Parasitol. 129, 299-311, http://dx.doi.org/10.1016/j.vetpar.2004.09.020.

Sampieri, B.R., Arnosti, A., Nunes, P.H., Furquim, K.C.S., Chierice, G.O., Mathias, M.I.C., 2012. Ultrastructural changes in the ovary cells of engorged Rhipicephalus sanguineus female ticks treated with esters of ricinoleic acid from castor oil (Ricinus communis). Microsc. Res. Tech. 75, 683-690, http://dx. doi.org/10.1002/jemt.21112.

Sauer, J., Hair, J.A., 1986. Morphology, Physiology, and Behavioural Biology of Ticks. Ellis Horwood Chichester.

Sayah, F., Fayet, C., Idaomar, M., Karlinsky, A., 1996. Effect of azadirachtin on vitellogenesis of Labidura riparia (Insect dermaptera). Tissue Cell 28, 741-749, http://dx.doi.org/10.1016/S0040-8166(96)80077-2.

Scudeler, E.L., Santos, D.C., 2013. Effects of neem oil (Azadirachta indica A. Juss) on midgut cells of predatory larvae Ceraeochrysa claveri (Navás, 1911) (Neuroptera: Chrysopidae). Micron 44, 125-132, http://dx.doi.org/10.1016/j. micron.2012.05.009.

Scudeler, E.L., Padovani, C.R., Dos Santos, D.C., 2014. Effects of neem oil (Azadirachta indica A. Juss) on the replacement of the midgut epithelium in the lacewing Ceraeochrysa claveri during larval-pupal metamorphosis. Acta Histochem. 116, 771-780, http://dx.doi.org/10.1016/j.acthis.2014.01.008.

Scudeler, E.L., Garcia, A.S.G., Padovani, C.R., Pinheiro, P.F.F., dos Santos, D.C., 2016. Cytotoxic effects of neem oil in the midgut of the predator Ceraeochrysa claveri. Micron 80, 96-111, http://dx.doi.org/10.1016/j.micron.2015.10.005.

Sexton, D.J., Burgdorfer, W., Thomas, L., Norment, B.R., 1976. Rocky Mountain spotted fever in Mississippi: survey for spotted fever antibodies in dogs and for spotted fever group Rickettsiae in dog ticks. Am. J. Epidemiol. 103, 192-197.

Silva de Moraes, R.L., Bowen, I.D., 2000. Modes of cell death in the hypopharyngeal gland of the honey bee (Apis mellifera 1). Cell Biol. Int. 24, 737-743, http://dx. doi.org/10.1006/cbir.2000.0534.

Soares, A.O., Souza, A.D., Feliciano, E.A., Rodrigues, A.F.S.F., D’Agosto, M., Daemon, E., 2006. Evaluation of ectoparasites and hemoparasites in dogs kept in apartments and houses with yards in the city of Juiz de Fora Minas Gerais. Brazil. Rev. Bras. Parasitol. Vet. 15, 13-16.
Sonenshine, D.E., Roe, R.M., 2014. Biology of Ticks, $2^{\mathrm{a}}$ ed. Oxford University Press, United States of America.

Stephen, S., Chandrashekara, I., Rao, K.N., 1980. Natural occurrence of Coxiella burnetii in the brown dog tick Rhipicephalus sanguineus. Indian J. Med. Res. 71, 865-869.

Szabó, M.P., Cunha, T.M., Pinter, A., Vicentini, F., 2001. Ticks (Acari: ixodidae) associated with domestic dogs in franca region, Sóo paulo, Brazil. Exp. Appl. Acarol. 25, 909-916, http://dx.doi.org/10.1023/A:1020433003028.

Till, W.M., 1961. A contribution to the anatomy and histology of the brown ear tick Rhipicephalus appendiculatus Neumann. Mem. Entomol. Soc. South. Africa 6, $1-124$.

Tomizawa, M., Casida, J.E., 2005. Neonicotinoid insecticide toxicology: mechanisms of selective action. Annu. Rev. Pharmacol. Toxicol. 45, 247-268, http://dx.doi.org/10.1146/annurev.pharmtox.45.120403.095930.

Uneme, H., Iwanaga, K., Higuchi, N., Kando, Y., Okauchi, T., Akayama, A., Minamida, I., 1999. Synthesis and insecticidal activity of nitroguanidine derivatives. Pestic. Sci. 55, 202-205, http://dx.doi.org/10.1002/(SICI)10969063(199902) 55:2<202:AID-PS869>3.0 (CO;2-G.).

Valotto, C.F.B., Silva, H.H.G., Da, Cavasin, G., Geris, R., Rodrigues Filho, E., Silva, Da, I.G., 2011. Alterações ultraestruturais em larvas de Aedes aegypti submetidas ao diterpeno labdano, isolado de Copaifera reticulata (Leguminosae), e à uma fração rica em taninos de Magonia pubescens (Sapindaceae). Rev. Soc. Bras. Med. Trop. 44, 194-200, http://dx.doi.org/10.1590/S003786822011005000010

Vendramini, M.C.R., Camargo-Mathias, M.I., Faria, A.U., Bechara, G.H., Oliveira, P.R., Roma, G.C., 2012. Cytotoxic effects of andiroba oil (Carapa guianensis) in reproductive system of Rhipicephalus sanguineus (Latreille, 1806) (Acari: Ixodidae) semi-engorged females. Parasitol. Res. 111, 1885-1894, http://dx. doi.org/10.1007/s00436-012-3031-6.

Wakita, T., Kinoshita, K., Yamada, E., Yasui, N., Kawahara, N., Naoi, A., Nakaya, M. Ebihara, K., Matsuno, H., Kodaka, K., 2003. The discovery of dinotefuran: a novel neonicotinoid. Pest Manag. Sci. 59, 1016-1022, http://dx.doi.org/10. $1002 /$ ps.727.

Wakita, T., Yasui, N., Yamada, E., Kishi, D., 2005. Development of a novel insecticide. Dinotefuran. J. Pestic. Sci. 30, 133-138, http://dx.doi.org/10.1584/ jpestics.30.133.

Wakita, T., 2011. Molecular design of dinotefuran with unique insecticidal properties. J. Agric. Food Chem. 59, 2938-2942, http://dx.doi.org/10.1021/ jf1030778.

Walker, A.R., Fletcher, J.D., 1987. Histology of digestion in nymphs of Rhipicephalus appendiculatus fed on rabbits and cattle naive and resistant to the ticks. Int. J. Parasitol. 17, 1393-1411.

Walker, J.B., Keirans, J.E., Horak, I.G., 2000. The Genus Rhipicephalus (Acari Ixodidae) A Guide to the Brown Ticks of the World. Cambridge University Press London.

Wall, R., Shearer, D., 1997. Veterinary Entomology. Chapman and Hall London.

Woldehiwet, Z., Ristic, M., 1993. Rickettsial and Chlamydial Diseases of Domestic Animals. Pergamon, Oxford.

Yoshinari, N.H., Barros, P.J.L., Bonoldi, V.L.N., Ishikawa, M., Battesti, D.M.B., Pirana, S., Fonseca, A.H. Schumaker, T.T. 1997. Perfil da borreliose de Lyme no Brasil: Rev. do Hosp. das Clínicas da Fac. Med. São Paulo 52, 111-117.

Zaim, M., Guillet, P., 2002. Alternative insecticides: an urgent need. Trends Parasitol. 18, 161-163, http://dx.doi.org/10.1016/S1471-4922(01)02220-6. 